\title{
Evaluation of Ice Thermal Energy Storage (ITES) for commercial buildings in cities in Brazil
}

\author{
Bruno Arcuri, Catalina Spataru, Mark Barrett \\ Energy Institute, University College London \\ 14 Upper Woburn Place, London, WC1H 0NN \\ contact email: bruno.arcuri.14@ucl.ac.uk
}

\begin{abstract}
High temperatures and the intensive use of air conditioning are considered the main drivers of the increase in Brazil's electricity demand in the summer, which has been causing major power cuts due to insufficient supply to meet peak demand. This paper analyses the techno-economic aspects of Ice Thermal Energy Storage (ITES) in Brazil, as a technology that can be used to shift building cooling load to off-peak time. ITES is assessed in five cities and five archetypes of commercial buildings, using two different operation strategies and two types of chillers, for new installations and retrofits. Results have shown that ITES can effectively shape peak demand in commercial buildings, generating economic gains for building owners but also losses in some cases. Although the climate plays an important role, the electricity tariffs vary significantly from city to city and this determined the economic feasibility of ITES. The technology's potential to shape demand in Brazil's commercial sector can encourage policy makers, regulators, grid operators and utilities in considering ITES as an option to reduce peak demand, increase security of supply and support the integration of intermittent renewable generation.
\end{abstract}

Keywords: Building cooling load; Economic analysis; Energy storage; Ice thermal energy storage; Peak demand; Tropical climates. 


\section{Introduction}

With high temperatures and the intensive use of air conditioning as the main drivers of the increase in Brazil's energy demand in the summer (EPE, 2014; EPE, 2015a), major power cuts due to insufficient supply to meet peak demand occurred on the 4th February of 2014, at 14:03, and on the 19th January of 2015, at 14:48 (MME, 2014; MME, 2015). Although Time-of-Use (ToU) tariffs in Brazil consider peak demand time to be from 17:00 to 20:00, the Government energy research agency (EPE) undertook a study to understand changes in the country's daily load profile. A significant load shift was noticed from current onpeak tariff time to off-peak tariff time in the summer, associated with the intensive use of air-conditioning (AC), while peak load continued to occur during on-peak tariff time in the winter (EPE, 2015b). Figure 1 and Figure 2 show how the country's daily load curve has been changing from 2000 to 2014 .

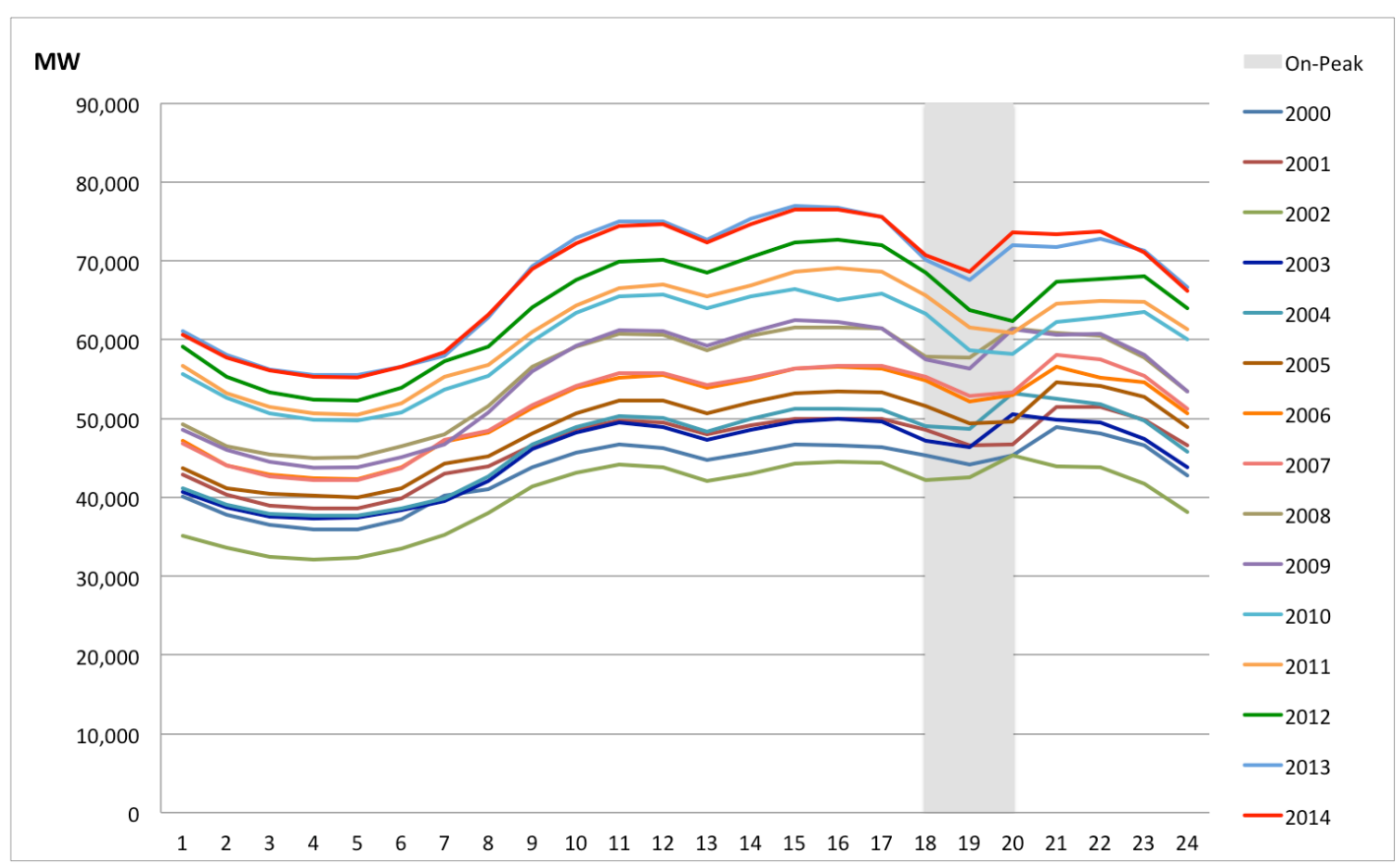

Figure 1 - Daily load curves in summer (Data source: EPE, 2015b) 


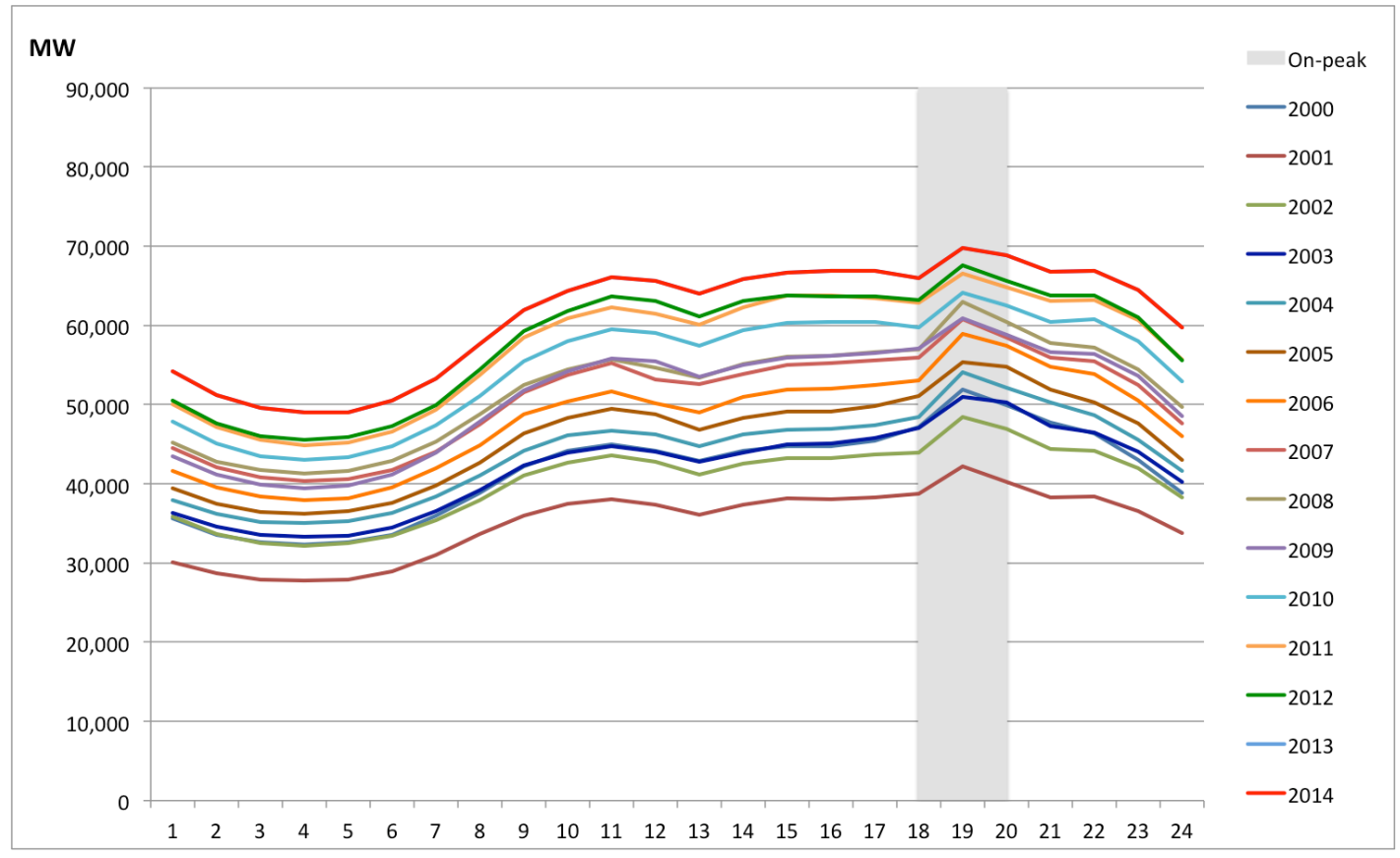

Figure 2 - Daily load curves in winter (Data source: EPE, 2015b)

As the impacts of the intensive use of air conditioning on the electric system are likely to increase, Cool Thermal Energy Storage (CTES) can be used to shift building cooling load to off-peak time and reduce peak electricity demand in the case of intensive air conditioning use (ASHRAE, 2007; Spataru et al., 2014). There are three types of CTES: Chilled Water Storage (CWS), Ice Thermal Energy Storage (ITES) and Phase Change Materials (PCMs) (Hasnain, 1998; Dinçer \& Rosen, 2011; Parameshwaran et al., 2012). PCMs used for CTES are eutectic salts that change phases (liquid/solid) at temperatures around $8^{\circ} \mathrm{C}$ (Dinçer \& Rosen, 2011). Table 1 presents a comparison of these three types of CTES systems.

Table 1 - Comparison of CTES systems (Yau \& Rismanchi, 2012)

\begin{tabular}{lccc}
\hline & CWS & ITES & $\begin{array}{c}\text { PCM } \\
\text { (Eutectic salts) }\end{array}$ \\
\hline Specific heat $(\mathbf{k J} / \mathbf{k g}-\mathbf{K})$ & 4.19 & 2.04 & - \\
Latent heat of fusion $\mathbf{( k J / k g )}$ & - & 333 & $80-250$ \\
Chiller type & Water & Secondary coolant & Water \\
Chiller cost $(\mathbf{\$} / \mathbf{k W})$ & $57-85$ & $57-142$ & $57-85$ \\
Tank volume $(\mathbf{m} \mathbf{3} / \mathbf{k W h})$ & $0.089-0.169$ & $0.019-0.023$ & 0.048 \\
Charging temperature $\left({ }^{\circ} \mathbf{C}\right)$ & 4 to 6 & -6 to -3 & 4 to 6 \\
Discharge temperature $\left({ }^{\circ} \mathbf{C}\right)$ & 1 to 4 & 1 to 3 & 9 to 10 \\
Chiller COP & 5 to 6 & 2.7 to 4 & 5 to 6 \\
Discharge fluid & Water & Secondary coolant & Water
\end{tabular}




\begin{tabular}{lccc} 
Tank interface & Open system & Closed system & Open system \\
Space requirements & More & Less & Less \\
Maintenance & High & Medium & Medium \\
\hline
\end{tabular}

It is believed that CWS and ITES are the most practical CTES methods, although PCMs have been receiving significant attention recently (Dinçer \& Rosen, 2011). ITES offers larger storage capacity, but presents lower Coefficient of Performance (COP) and does not benefit significantly from economies of scale, while CWS can benefit significantly from economies of scale but requires much more available space (Bahnfleth \& Reindl, 1998; Hasnain, 1998; Dinçer \& Rosen, 2011). Since CTES and air-conditioning (AC) work often involves retrofit, where space is a concern, ITES is the likely choice for individual commercial and institutional buildings, while CWS is the preferred system for industrial and district cooling sites.

The literature involving case studies of ITES for commercial buildings is vast and often concludes that the use of ITES systems can generate benefits for consumers and utilities. Sohn et al. (1990) and Akbaru \& Sezgen (1992) assessed ITES retrofits in commercial buildings in the U.S. Beggs \& Ward (1992) highlighted that potential savings from the use of an ITES system can be nullified completely if the operation strategy is not adequate. Crane \& Dunlop (1994) reported an ITES system installed in a department store in Oxford Street, London. Henze (1995) carried a simulation-based investigation of 360 combinations of ITES technologies, chillers, commercial buildings, weather and rate structures in the U.S. Habeebullah (2007) has conducted an economic feasibility study of the use of ITES for the Grand Holy Mosque of Makkah, Saudi Arabia, and found no economic gains for ITES with the country's subsidised electricity tariff. Donnely (2012) reviews the methods used in the design of an ITES system in the Carroll's building in Dundalk IT, Ireland, where ice-banks store the excess electricity produced by a wind turbine. Sehar et al. (2012) assessed the use of ITES for large and medium-sized office buildings in U.S. cities with different climate conditions. ITES systems were also assessed for commercial buildings in Malaysia by Rismanchi et al. $(2012 ; 2013)$. Yin et al. (2015) simulated ITES in office and retail buildings in California to assess its cost-effectiveness and demand response (DR) capabilities, and concluded that ITES can provide a reliable and fast load shed without interruption in the buildings occupants' comfort. Wu \& Yao-Hsu (2015) concluded that the main driver for the uptake of ITES technology is economic. Sehar et al. (2016) 
simulates a medium-sized office building with integrated solar PV, DR and ITES.

However, based on the author's knowledge, there is very limited evidence and studies related to potential energy and cost savings of using ITES systems in Brazil. Alpina CALMAC (2007), currently the only ITES manufacturer in Brazil, presents the technical details and specifications of ITES systems installed in offices buildings, shopping centres and supermarkets in Brazil. In a report by SMACNA BRASIL (1993), the use of ITES is considered one of the main methods of energy conservation in AC systems. Cortez et al. (2003) suggests that ITES can generate economic benefits for commercial consumers in Brazil even though total energy consumption might increase. Vieira (2009) suggests changes in the structure of tariffs in Brazil placing CTES as strategic to shift load from daytime to night-time. Condessa \& Neto (2014) designed and assessed an ITES system for one of the campus of a faculty.

\subsection{Aims and objectives}

The use of ITES suggests that commercial consumers adopting ToU tariffs in Brazil would possibly benefit from lower energy costs. This research aims to fill the gap of evidence by assessing the benefits of ITES technology for wider scale integration in Brazil's commercial sector. To design and assess ITES systems in Brazil, this study establishes the cooling load profile for different archetypes of commercial buildings in Brazil. Therefore, an important contribution from this research effort is to make the case for the development of a library of cooling load profiles for Brazil's commercial building stock. The research objectives are to assess how effectively ITES can shape peak demand in Brazil's commercial sector and provide savings with tariffs for commercial consumers, and if the solution is economically viable for new and retrofit installations in commercial buildings in Brazil.

\section{Commercial buildings in Brazil}

The national programme for electrical energy conservation (PROCEL) collected energy consumption data from 953 representative consumers in the high voltage commercial sector (PROCEL, 2008). Figure 3 shows how the sample was divided in terms of types of buildings, subgroups and tariffs. 


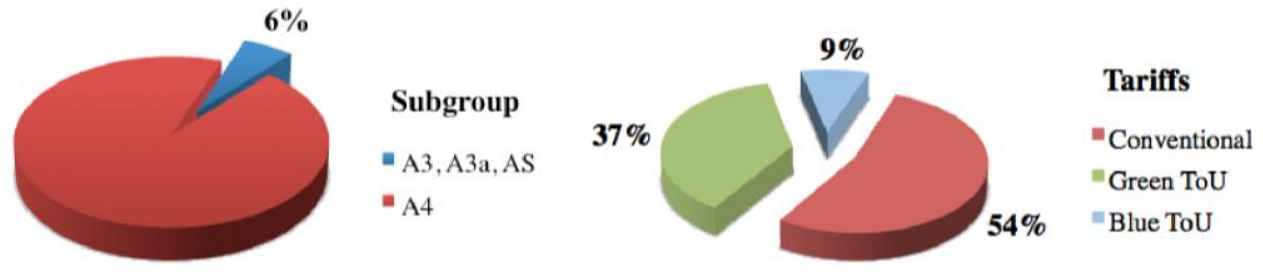

94\%

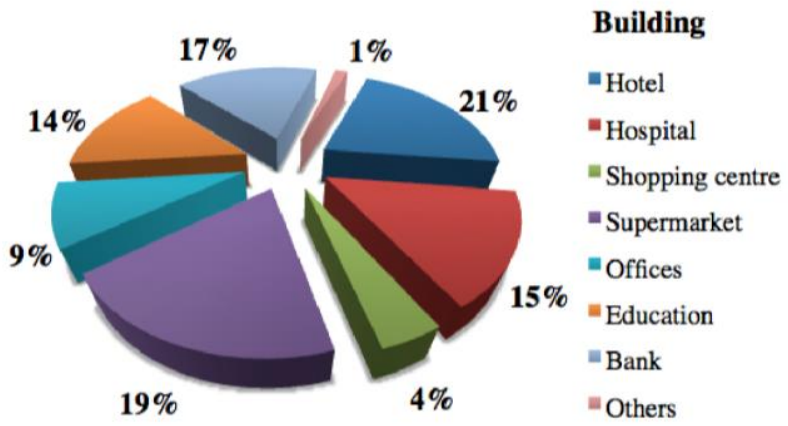

Figure 3 - Commercial buildings, subgroups and tariffs (Data source: PROCEL, 2008)

In terms of air conditioning types, $76.6 \%$ of the buildings used packaged air units, $25.1 \%$ used root-top/self-contained units and $16.2 \%$ chilled water systems. Only $2.3 \%$ of the consumers ( 22 out of 953 ) related the use of CTES. The types of consumers that used CTES were hotels, shopping centres, supermarkets and offices. Figure 4 shows the load of the chilled water system in comparison to the peak load demand of each type of building.

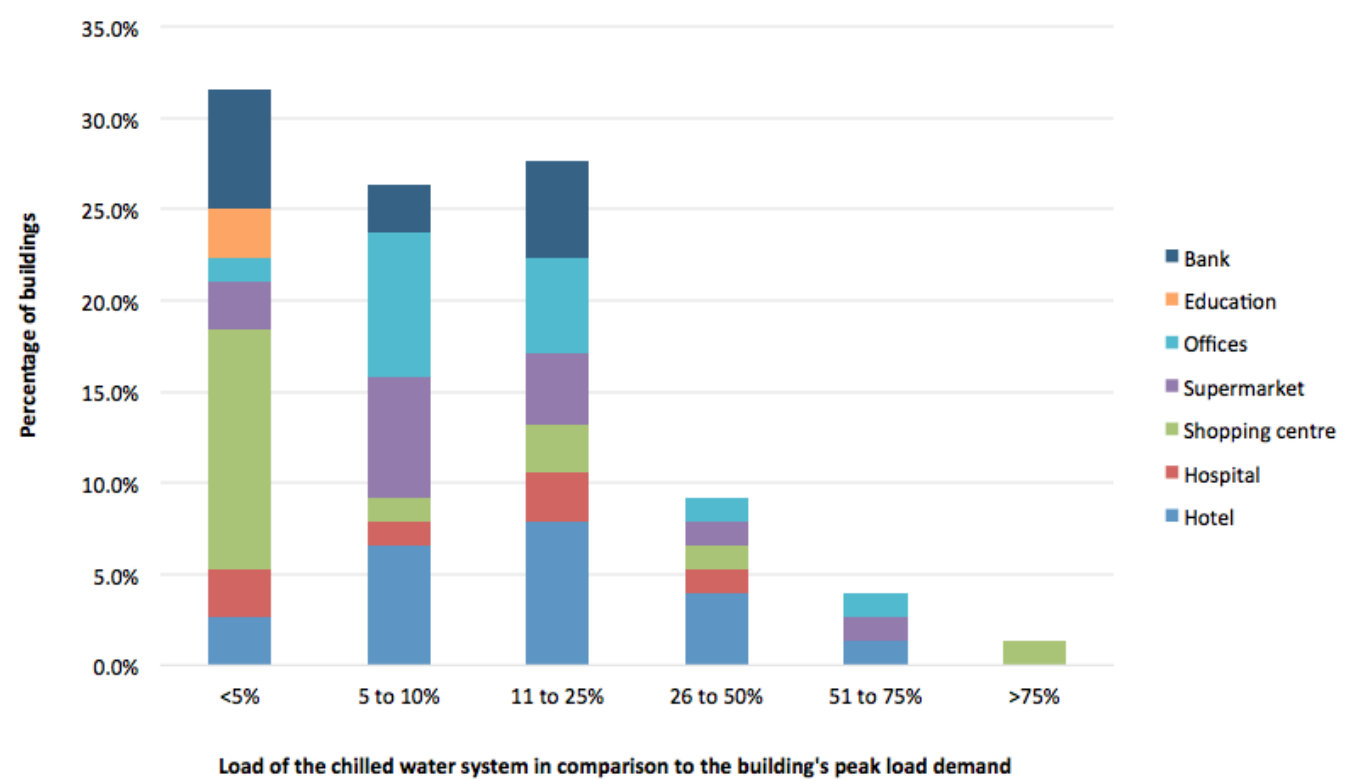

Figure 4 - Load of the chilled water system in comparison to the building's peak load demand (Data source: PROCEL, 2008)

This study by PROCEL is still the most detailed database related to energy 
consumption data in commercial buildings available in Brazil. However, the research was undertaken before the release of the Regulation for Energy Efficiency Labelling of Commercial Buildings (RTQ-C), released in February 2009 (INMETRO, 2012), and does not offer information on how the buildings relate to current or past energy efficiency standards.

The RTQ-C classifies commercial buildings in five levels, from the most to the least efficient (A to E), and can be based on hourly building energy simulations or on the use of a prescriptive method. According to Melo et al. (2014), most of building energy efficiency standards being implemented in many countries are based on the ANSI/ASHRAE Standard 90.1 - Energy Standard for Buildings Except Low-Rise Residential Buildings, which establishes minimum requirements for efficient buildings. Melo et al. (2014) compared the building energy performance assessment between ANSI/ASHRAE Standard 90.1-2007 and the RTQ-C in Brazil, and found equivalence between levels A to $\mathrm{C}$ of the Brazilian regulation and the reference model from ANSI/ASHRAE Standard 90.1-2007 for commercial buildings, depending on the climate adopted.

\section{Methodology}

Given the aims of this research and the limitation imposed by the lack of in-situ measurements, modelling is the method used to assess ITES for commercial buildings in Brazil. This research assesses ITES case studies represented by five cities, five archetypes of commercial buildings in Brazil, two different operation strategies and two types of chiller. Firstly, to design and assess conventional and ITES cooling systems it is necessary to establish a design day cooling load profile. Secondly, the conventional system is designed to attend the building's cooling load as demanded, while the ITES systems are designed to reduce demand charges and eliminate on-peak time energy consumption. It is assumed that the cooling is supplied by a chilled water system composed of a chiller, ice storage tanks and a mean to deliver chilled water/air to the occupied space. Thirdly, the conventional and the ITES systems are compared in terms of energetic performance and economic feasibility.

\subsection{Modelling}

\subsubsection{Commercial buildings cooling load profiles}

According to ASHRAE (2001), there are several methods to calculate the cooling load profile of a commercial building. The heat balance (HB) method applies 
heat transfer calculations with the construction elements of the building (walls, floor, windows, skylights, furniture, ceiling, slab, and roof). Other simplified methods are available including the radiant time-series (RTS), the transfer function (TFM), the total equivalent temperature differential with time averaging (TETD/TA) and the cooling load temperature difference with cooling load factors (CLTD/CLF) methods. Previous research assessed the use of ITES estimating the building cooling load profile of commercial buildings with the CLTD/CLF method (Rismanchi et al., 2012), the TFM method (Wu \& Yao-Hsu, 2015) and, simulation tools such as TRNSYS (Rismanchi et al., 2013) and Energy Plus (Sehar et al., 2012; Sehar et al., 2016; Yin et al., 2015).

The objective of this research is to compare the energetic performance and economic feasibility of ITES compared to a conventional system, and not to design a "real" AC system, which would require a detailed analysis from an experienced designer in the field. Therefore, this research uses a simplified approach to the Heat Balance (HB) method proposed by ASHRAE (2001), using heat sources and heat gain calculation concepts. The total cooling load is estimated to be the sum of the conduction, solar radiation, internal and infiltration gains for each hour of the design day, as presented in the following equations.

$$
Q_{\text {total }}=Q_{\text {cond }}+Q_{\text {rad }}+Q_{i n t}+Q_{i n f}
$$

Conduction gains are represented by:

$$
Q_{\text {cond }}=Q_{c o n d, \text { roof }}+Q_{c o n d, w a l l}+Q_{c o n d, w i n d o w}
$$

where,

$$
Q_{\text {cond }, i}=U_{i} A_{i}\left(T_{o}-T_{i}\right)
$$

$\mathrm{U}_{\mathrm{i}}$ is the heat transfer coefficient (U-value), $A_{\mathrm{i}}$ is the respective area and, $T_{o}$ and $T_{i}$ are the outside and inside air temperature respectively. The solar radiation gains through the windows are represented by:

$$
Q_{\text {rad }}=A_{\text {window }} I_{S} S H G C I A C
$$

where $A_{\text {window }}$ is the window area facing a certain orientation, $I_{s}$ is the solar 
radiation on a vertical surface facing a certain orientation, SHGC is the window's solar heat gain coefficient and IAC the inside shading attenuation coefficient. Internal gains are represented by:

$$
\mathbf{Q}_{\text {int }}=\mathbf{Q}_{\text {int,lights }}+\mathbf{Q}_{\text {int,people }}+\mathbf{Q}_{\text {int,appliances }}
$$

Infiltration gains are represented by:

$$
Q_{\text {inf }}=V_{\text {inf }} \rho_{\text {air }} c_{p}\left(T_{o}-T_{i}\right)
$$

where $V_{\text {inf }}$ is the infiltration rate, $\rho_{\text {air }}$ is the air density and $c_{p}$ is the specific heat capacity of air.

\subsubsection{Conventional and ITES cooling systems design}

Firstly, an ITES system is designed to only eliminate the chiller's operation during on-peak time, supplying full storage from 17:00 to 20:00 (ITES 1). Secondly, an ITES system is design to eliminate the chiller's operation during on-peak time and reduce demand charges, supplying full storage from 17:00 to 20:00 and partial storage from 8:00 to 17:00 and 20:00 to 22:00 (ITES 2). Icemaking time is considered to be from 22:00 to 8:00 for both strategies. In an ITES system the building peak load (TR) does not define the required chiller capacity as in a conventional system. Rather, the total cooling load (TRh) needs to be met by the chiller over its entire operating period. The set of equations used to size an ITES system is presented below, as described by Silvetti (2002).

Chiller $_{\text {total capacity }}(\mathrm{TRh})=$ Chiller $_{\text {cooling capacity }}(\mathrm{TRh})+$ Chiller $_{\text {ice capacity }}(\mathrm{TRh})($

$$
\begin{gathered}
\text { Chiller }_{\text {cooling capacity }}(T R h)=\text { Chiller }_{\text {size }}(T R) . F_{\text {safety }} \cdot \boldsymbol{h}_{\text {cooling }} \\
\text { Chiller }_{\text {ice capacity }}(T R h)=\text { Chiller }_{\text {size }}(T R) . F_{\text {derating }} \cdot \boldsymbol{h}_{\text {ice-making }}
\end{gathered}
$$

then,

$$
\operatorname{Chiller}_{\text {size }}(\mathrm{TR})=\frac{\text { Chiller }_{\text {total capacity }}(\mathrm{TRh})}{h_{\text {cooling }}+\text { derating } \cdot h_{\text {ice-making }}}
$$


The derating factor $\left(F_{\text {derating }}\right)$, which accounts for the reduced rate of heat transfer affected by the ice buildup thickness, is directly related to the system's design and manufacturer's specifications, usually varying between $65-75 \%$ for compressor chillers (Rismanchi et al., 2012; Silvetti, 2002). CALMAC's Ice Pick is the software used by Alpina CALMAC to size ITES systems in Brazil. Ice Pick requires the building's cooling load profile, operation strategy (ice making, cooling and partial/full storage times), chiller/storage priority, temperatures of the supply and return water-glycol solution, chiller capacity (ice making, cooling and partial/full storage) and ice tank model. Figure 5 illustrates the ITES system equipment, water circuit and temperatures in each part of the cooling process based on design guidance provided by Alpina CALMAC (2016a) and Trane (2009).

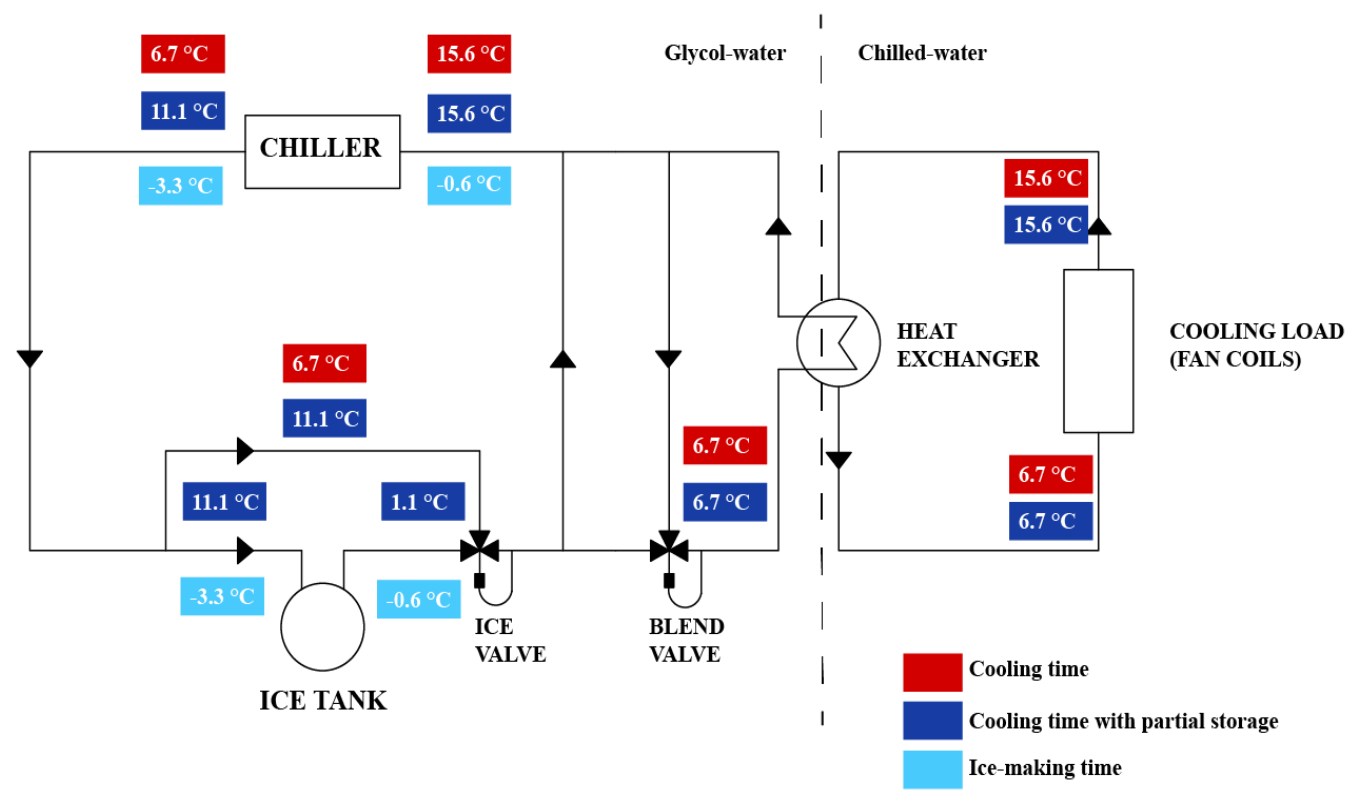

Figure 5 - ITES engineering design

\subsection{Energetic analysis}

As the systems are designed in $\mathrm{kW}$ of heat or Tons of Refrigeration (TR), it is necessary to assume COP values for the chiller to estimate the electricity consumption. This research uses the approach presented by Henze (1995), in which the variation of the plant's actual COP due to changes in ambient conditions is proportional to the change in the COP of a Carnot refrigeration cycle. An estimate of the actual COP $\left(\mathrm{COP}_{a c t, 2}\right)$ at any $T_{u, 2}$ and $T_{l, 2}$ can be found from the actual COP $\left(\mathrm{COP}_{a c t, 1}\right)$ provided by the chiller manufacturer at operating temperatures $T_{u, 1}$ and $T_{l, 1}$ is assumed to be: 


$$
C O P_{a c t, 2}=\frac{\frac{T_{u, 2}}{T_{u, 2}-T_{l, 2}}}{\frac{T_{u, 1}}{T_{u, 1}-T_{l, 1}}} \text { COP } P_{a c t, 1}
$$

where $T_{u}$ and $T_{l}$ are the upper (condenser) and the lower (evaporator) process temperatures, respectively.

\subsection{Economic analysis}

The economic analysis evaluates if the adoption of ITES can generate savings with electricity tariffs and estimates the economic feasibility for both new and retrofit ITES installations. The Capital Expenditure (CAPEX) is assessed using the Payback period (PB) and the Internal Rate of Return (IRR). The payback period $(\mathrm{PB})$ is estimated by:

$$
P B=\frac{C A P E X}{\text { Annual savings with tariffs }}
$$

The IRR is the discount rate $r$ when:

$$
N P V=\sum_{n-0}^{N} \frac{C_{n}}{(1+r)^{n}}=0
$$

where $C_{n}$ is the cash flow and $n$ the period. This research assumes that, for new installations, the investment represents the capital costs of the chiller and ice tanks for both conventional and ITES cooling systems. For retrofits, only the costs of acquiring the ice tanks are considered.

\subsection{Data collection}

\subsubsection{Weather and electricity tariffs}

Five cities in Brazil were chosen to represent different weather and electricity

\begin{tabular}{|c|c|c|c|c|}
\hline City & $\begin{array}{c}\text { Population } \\
\text { (IBGE, 2016) } \\
\end{array}$ & $\begin{array}{c}\text { Latitude } \\
(\text { SWERA, 2016) } \\
\end{array}$ & $\begin{array}{c}\text { Climate* }^{*} \\
\text { (SWERA, 2016) }\end{array}$ & Energy Supplier \\
\hline Recife & $1.617 \mathrm{mi}$ & $8^{\circ} \mathrm{S}$ & $\begin{array}{l}\text { 1A, Very Hot - Humid, } \\
\text { Tropical Wet-and-Dry }\end{array}$ & Celpe \\
\hline Salvador & $2.675 \mathrm{mi}$ & $13^{\circ} \mathrm{S}$ & $\begin{array}{l}\text { 1A, Very Hot - Humid, } \\
\text { Tropical Wet-and-Dry }\end{array}$ & Coelba \\
\hline
\end{tabular}
tariffs, as shown in Table 2.

Table 2 - Cities: Population size, latitude, climate and energy supplier 


\begin{tabular}{|c|c|c|c|c|}
\hline Rio de Janeiro & $6.476 \mathrm{mi}$ & $21^{\circ} \mathrm{S}$ & $\begin{array}{l}\text { 1A, Very Hot - Humid, } \\
\text { Tropical Wet-and-Dry }\end{array}$ & Light \\
\hline São Paulo & $11.967 \mathrm{mi}$ & $24^{\circ} \mathrm{S}$ & $\begin{array}{l}\text { 3A, Warm - Humid, } \\
\text { Humid Subtropical }\end{array}$ & AES Eletropaulo \\
\hline Florianópolis & $0.469 \mathrm{mi}$ & $27.4^{\circ} \mathrm{S}$ & $\begin{array}{l}\text { 2A, Hot - Humid, } \\
\text { Humid Subtropical }\end{array}$ & Celesc \\
\hline
\end{tabular}

*Climate classification according to ASHRAE Standards 90.1 and 90.2

The TMY (typical meteorological year) weather data are available at SWERA (2016) and the vertical solar radiation on North, South, West and East surfaces are available at Frota \& Schiffer (2011). In terms of tariffs, this research considers commercial consumers of the subgroup A4 as presented in Table 3.

Table 3 - Tariffs for subgroup A4 consumers in Brazil

\begin{tabular}{|c|c|c|c|c|c|c|c|c|c|c|c|}
\hline & & \multicolumn{2}{|c|}{$\begin{array}{c}\text { Recife } \\
\text { (Celpe, 2016) }\end{array}$} & \multicolumn{2}{|c|}{$\begin{array}{c}\text { Salvador } \\
\text { (Coelba, } \\
2016)\end{array}$} & \multicolumn{2}{|c|}{$\begin{array}{c}\text { Rio de } \\
\text { Janeiro } \\
\text { (Light, 2016) }\end{array}$} & \multicolumn{2}{|c|}{$\begin{array}{l}\text { São Paulo } \\
\text { (AES } \\
\text { Eletropaulo, } \\
\text { 2016) }\end{array}$} & \multicolumn{2}{|c|}{$\begin{array}{c}\text { Florianópolis } \\
\text { (Celesc, } \\
\text { 2016) }\end{array}$} \\
\hline & & $\begin{array}{c}\text { On } \\
\text { Peak } \\
\end{array}$ & $\begin{array}{c}\text { Off } \\
\text { Peak } \\
\end{array}$ & $\begin{array}{c}\text { On } \\
\text { Peak }\end{array}$ & $\begin{array}{c}\text { Off } \\
\text { Peak }\end{array}$ & $\begin{array}{c}\text { On } \\
\text { Peak } \\
\end{array}$ & $\begin{array}{c}\text { Off } \\
\text { Peak } \\
\end{array}$ & $\begin{array}{c}\text { On } \\
\text { Peak } \\
\end{array}$ & $\begin{array}{c}\text { Off } \\
\text { Peak }\end{array}$ & $\begin{array}{c}\text { On } \\
\text { Peak }\end{array}$ & $\begin{array}{c}\text { Off } \\
\text { Peak } \\
\end{array}$ \\
\hline \multirow{2}{*}{ Blue } & $\mathbf{R} \$ \mathbf{k W}$ & 49.31 & 49.31 & 68.70 & 23.99 & 37.85 & 20.00 & 16.92 & 10.57 & 36.35 & 13.56 \\
\hline & $\mathbf{R} \$ / \mathbf{k W h}$ & 0.55 & 0.37 & 0.52 & 0.36 & 0.83 & 0.60 & 0.50 & 0.36 & 0.70 & 0.48 \\
\hline \multirow{2}{*}{ Green } & $\mathbf{R} \$ / \mathbf{k W}$ & 16.89 & 16.89 & 23.99 & 23.99 & 20.00 & 20.00 & 10.57 & 10.57 & 13.56 & 13.56 \\
\hline & $\mathbf{R} \$ / \mathbf{k W h}$ & 1.75 & 0.37 & 2.19 & 0.36 & 1.75 & 0.60 & 0.91 & 0.36 & 1.61 & 0.48 \\
\hline
\end{tabular}

Table 3 demonstrates that Blue tariffs charge higher contract tariffs $(\mathrm{R} \$ / \mathrm{kW})$ and lower consumption tariffs $(\mathrm{R} \$ \mathrm{kWh})$ than Green tariffs. Moreover, tariffs in Salvador are higher than the tariffs in other cities, especially when compared to São Paulo, which presents the lower tariffs.

\subsubsection{Commercial buildings}

Based on the report by PROCEL (2008), only five archetypes are considered: Medium and large sized offices, hospital, hotel and school. The logic behind the chosen archetypes is based on the following:

- a bank can be defined as an office building;

- a shopping centre is an archetype that can vary widely in terms of size, geometry, functions and occupancy, and a dedicated study would be needed;

- supermarkets make intensive use of refrigeration units that demand cooling for reasons other than space cooling, and a study dedicated to this archetype 
would be needed.

As reference models for commercial buildings in Brazil are still not available, and based on the findings by Melo et al. (2014) described in section 2, this research assumes that the U.S. Department of Energy (DOE) reference buildings can be used to develop cooling load profiles for the chosen archetypes. The U.S. DOE reference models comply with the minimum requirements of ANSI/ASHRAE Standard 90.1 and are purposed to serve as starting points for energy efficiency research (NREL, 2011). The dataset used in this study includes type, geometry, areas (roof, wall, window, floor), window facing direction, heat transfer coefficients, solar heat gain coefficient, occupancy, lightning, appliances and infiltration levels.

\subsubsection{Chiller and ice tanks}

The data related to the chiller was collected from manufacturers' technical catalogues. Also, a number of installers in Brazil were contacted via phone and email. The research assumes two types of chillers: air-cooled (Carrier's screw chillers AQUAFORCE® 30XA) and water-cooled (AQUAFORCE® 30XW). The data for ice tanks were collected from manufacturers' technical catalogues and from Alpina CALMAC (2016a; 2016b). CALMAC's IceBank model C 1190 is an internal melt ice-on-coil ITES technology and according to the manufacturer is the most used ice tank model in Brazil due to size and performance specifications.

Table 4 - Estimated costs for HVAC and ITES equipment for the Brazilian market (Data source: Climapress, 2016; Alpina CALMAC, 2016b)

\begin{tabular}{lcc}
\multicolumn{1}{c}{ Description } & Model & R\$/Unit* \\
\hline Air-cooled chiller & AQUAFORCE 30XA & 2,287 \\
Water-cooled chiller & AQUAFORCE 30XW & 1,757 \\
Cooling Tower/Condenser circuit & - & 1,005 \\
Ice Tank & CALMAC C 1190 & 45,000 \\
\hline
\end{tabular}

*Per TR for chillers and cooling tower/condenser circuit. Per tank for ice tanks.

Although water-cooled chillers present lower prices per unit in comparison to aircooled chillers, the cooling tower/condenser circuit needs to be considered in this case. Overall, water-cooled systems would present higher capital costs than aircooled systems. 


\subsection{Limitations}

The research aims to assess the benefits of ITES for commercial buildings in Brazil, therefore, the cooling load calculation is one of the steps but not the main focus of the research. By using the U.S. DOE's reference buildings dataset, it is acknowledged that the cooling load calculations might not fully represent Brazil's commercial building stock. The buildings' cooling load profiles also does not take into account more complex physical interactions within the building and gives only an estimation of the amount of heat an air conditioning (AC) system would need to remove in order to keep the temperature below a certain set point. The building is considered to be a single zone space filled with air, assuming no interior walls, furniture, etc., and the internal temperature is considered to be constant at $23^{\circ} \mathrm{C}$. Only sensible heat is considered. Commercial buildings can use a wide range of $\mathrm{AC}$ systems including direct expansion air packaged and rooftop/self-contained units, however, only chilled water AC systems (indirect-expansion) are considered in the study. ITES technologies such as the Ice Bear (Ice-Energy, 2016) are a solution for direct-expansion systems, however, the engineering concept differs significantly from the one approached in this research. A real AC system also has secondary systems such as pumping, cooling towers, piping, airside and control systems which are not considered in the research. Moreover, the CAPEX only considers the costs of the chiller (cooling tower and condenser circuit for the water-cooled case) and storage. In real life new or retrofit installations, costs may vary significantly depending on the location and conditions of the building.

\section{Results and discussion}

\subsection{Cooling load profiles}

The model outputs consist of design day cooling load profiles in $W / \mathrm{m}^{2}$ of heat for commercial buildings in different cities in Brazil, as shown in Figure 6. 

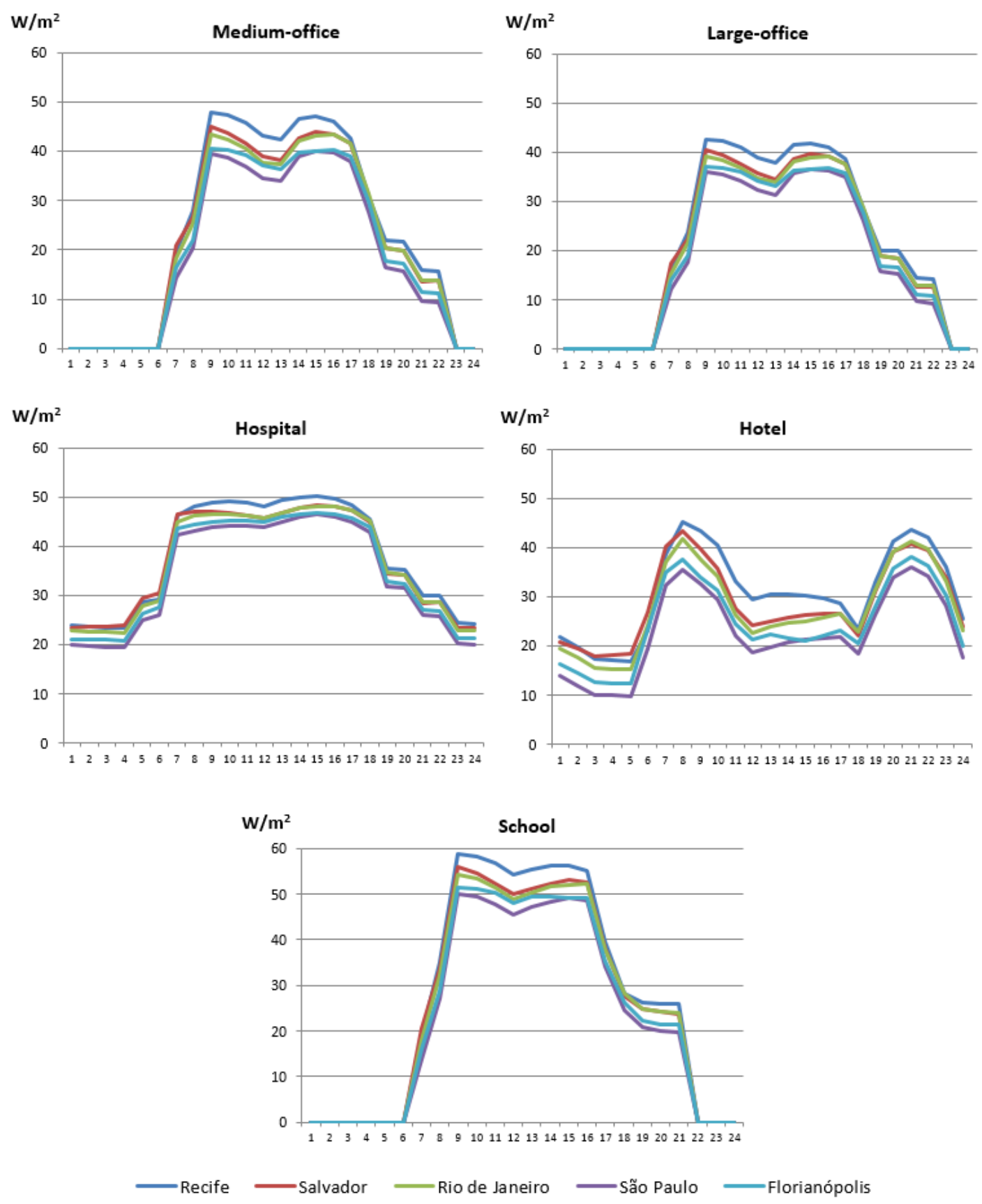

Figure 6 - Design day cooling load profiles $\left(\mathrm{W} / \mathrm{m}^{2}\right)$

Based on the design day cooling load profiles, conventional, ITES 1 and ITES 2 systems were designed for medium-office, large-office and school buildings. For hospital and hotel buildings, the chiller provides night-time cooling at the same time it produces ice. Due to reduced chiller capacity during ice-making time (derating factor, 65\%), ITES 2 systems are not designed for hospital and hotel buildings as the gains of reducing daytime demand are compensated by higher demand during night-time. 
ITES 1 systems only produce ice to eliminate chiller operation during on-peak time, therefore it does not downsize the chiller in comparison to a conventional system. On the other hand, in medium-office, large-office and school buildings, when the ITES system is designed to also offer partial storage (ITES 2) the chiller is downsized. Figure 7 shows the operation of AC systems in the city of Recife for a large-office building. The operational curves are similar in other cities, as well as in the medium-office and school cases, following the cooling load profiles shown in Figure 6.

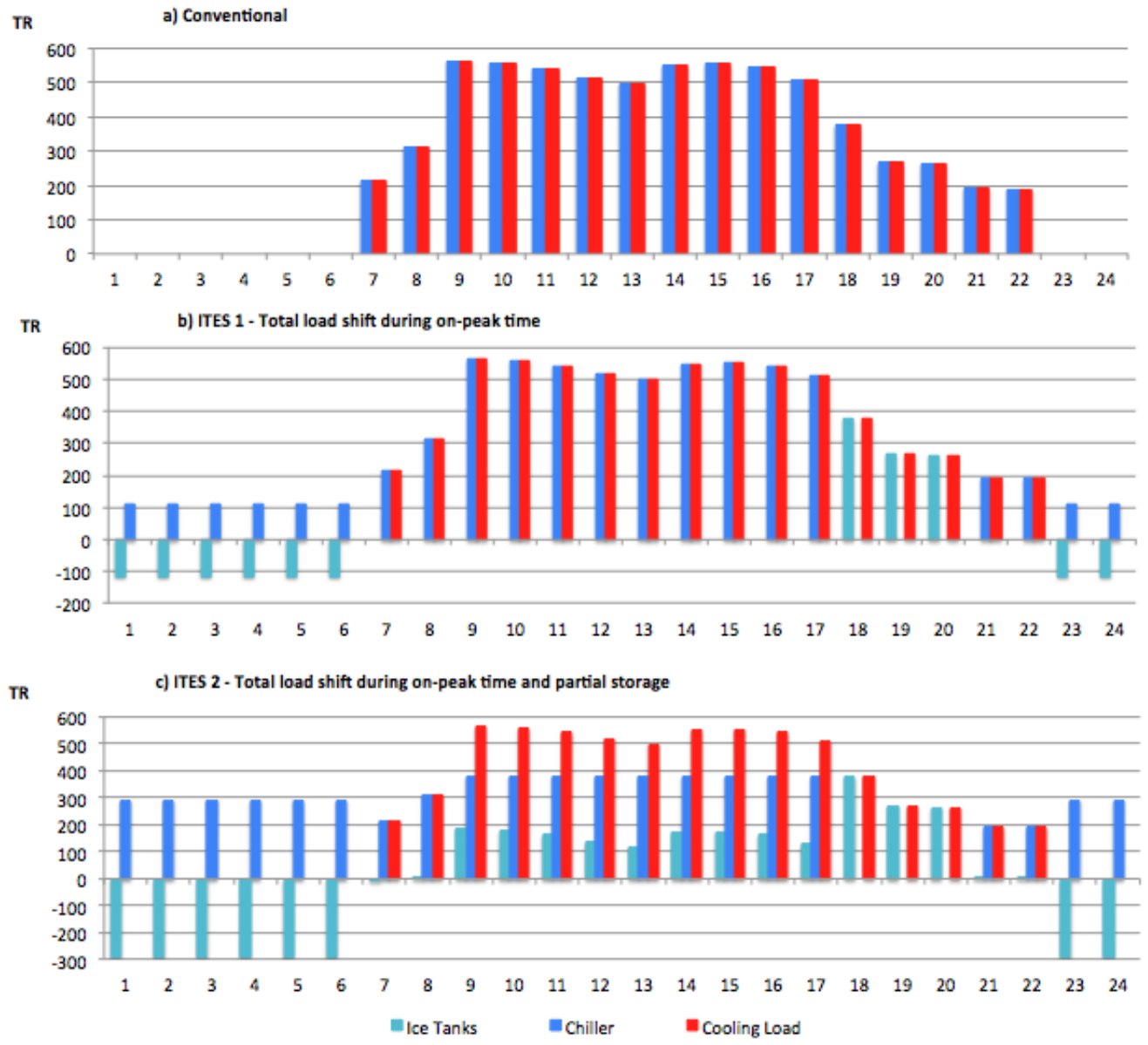

Figure 7 - Cooling systems on design day for a large-office in Recife

As mentioned before, due to night-time cooling load and reduced chiller capacity, only ITES 1 systems are designed for hospital and hotel buildings. Figure 8 and Figure 9 show the operation of conventional and ITES 1 systems in the city of Recife for a hospital and a hotel building, respectively. The operational curves are similar in other cities, following the cooling load profiles shown in Figure 6. 

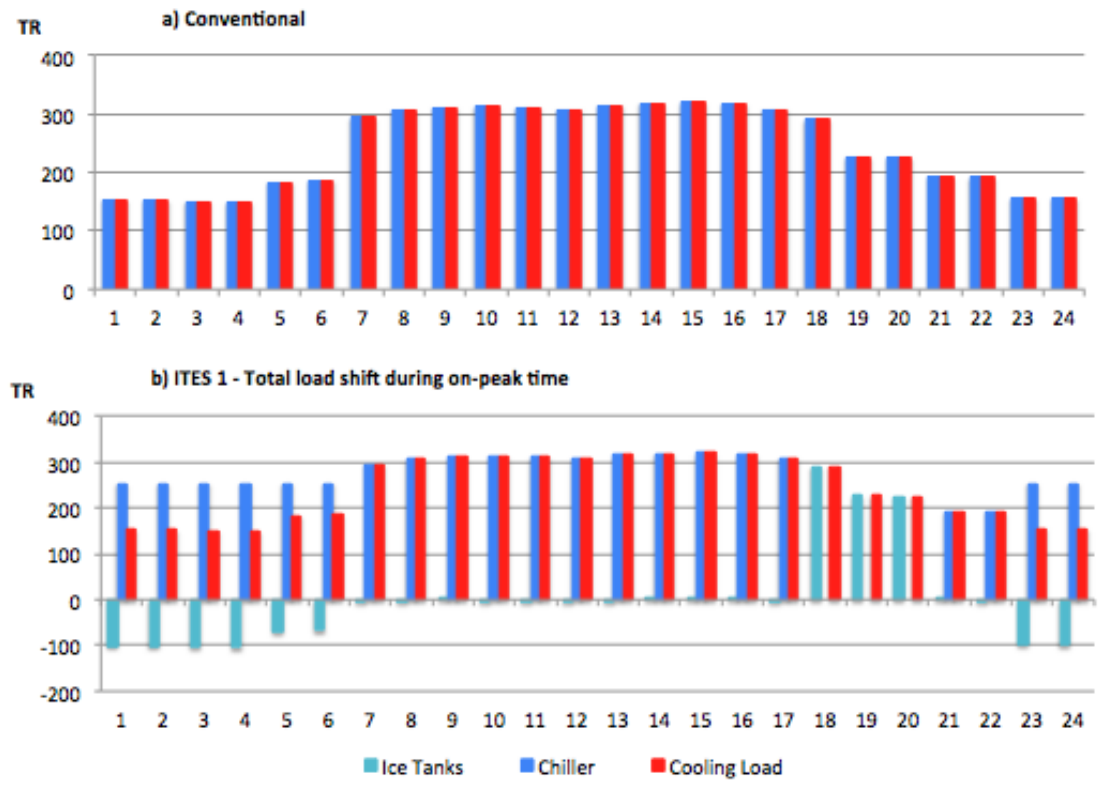

Figure 8 - Cooling systems on design day for a hospital in Recife

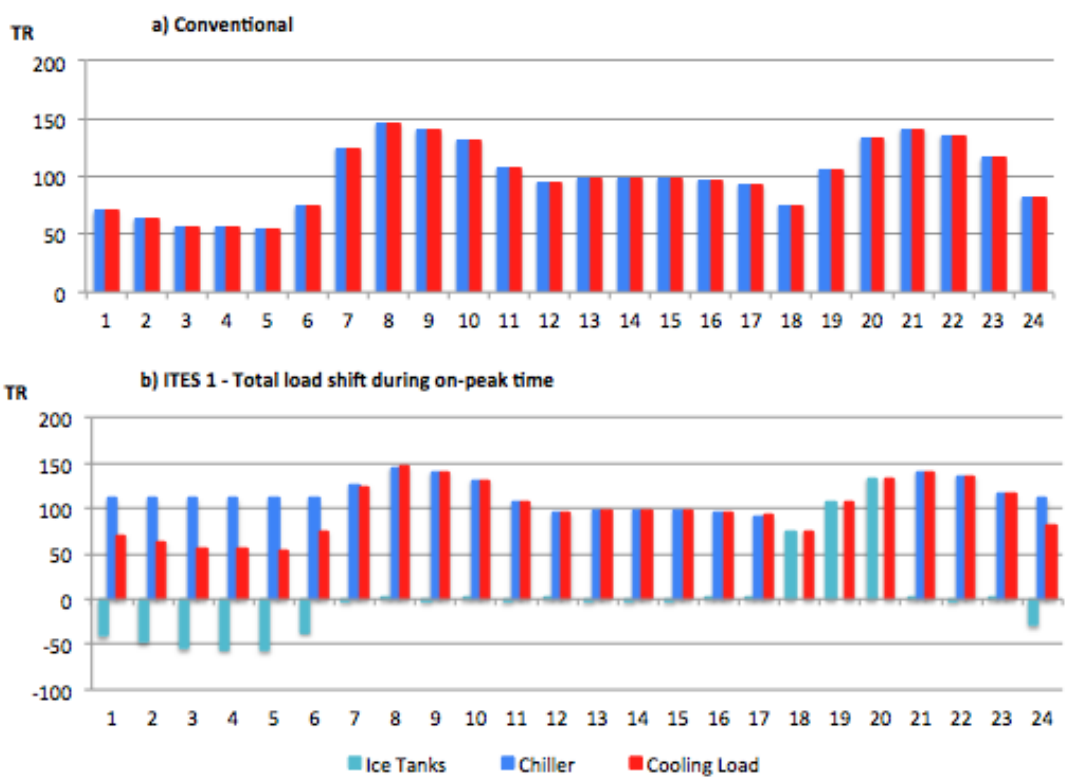

Figure 9 - Cooling systems on design day for a hotel in Recife

\subsection{Energetic performance}

The chiller's COP varies according to the chiller's type, weather conditions and ITES strategies. Previous research indicate that the COP during ice-making time is generally lower than the daytime's COP, due to the lower temperature on the chiller's evaporator necessary to make ice. Studies by Sohn et al. (1990), Beggs \& Ward (1992) and Akbaru \& Sezgen (1992) pointed to penalties varying from 23 to $40 \%$ for the ice-making COP. MacCracken $(2003 ; 2010)$ argues that lower 
ambient temperatures at night can make the ice-making process more efficient. This might be true for air-cooled chillers as the outdoor dry-bulb temperature at night can drop about the same as the temperatures on the evaporator needed to make ice. For water-cooled chillers, the ice-making efficiency may drop more significantly because the outdoor wet-bulb temperature does not drop as much as the temperatures on the evaporator needed to make ice. Using the approach described in section 3.2, Figure 10 and Figure 11 show how the COP varies depending on the climate for air and water-cooled chillers, respectively.
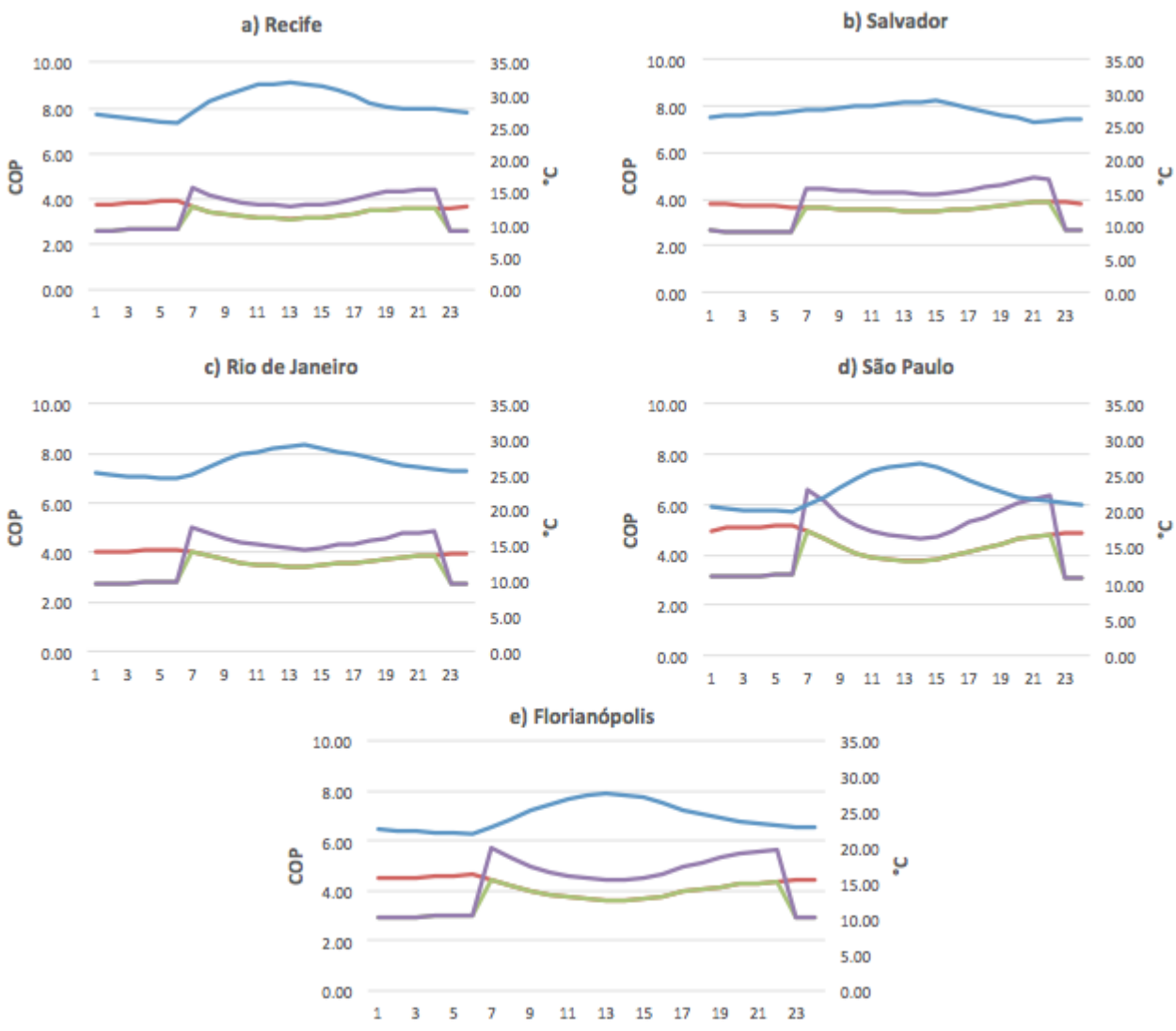

- COP Conventional - COP ITES 1 -COP ITES 2 -Dry-Bulb temperature

Figure 10 - COP curves for an air-cooled chiller on design day 

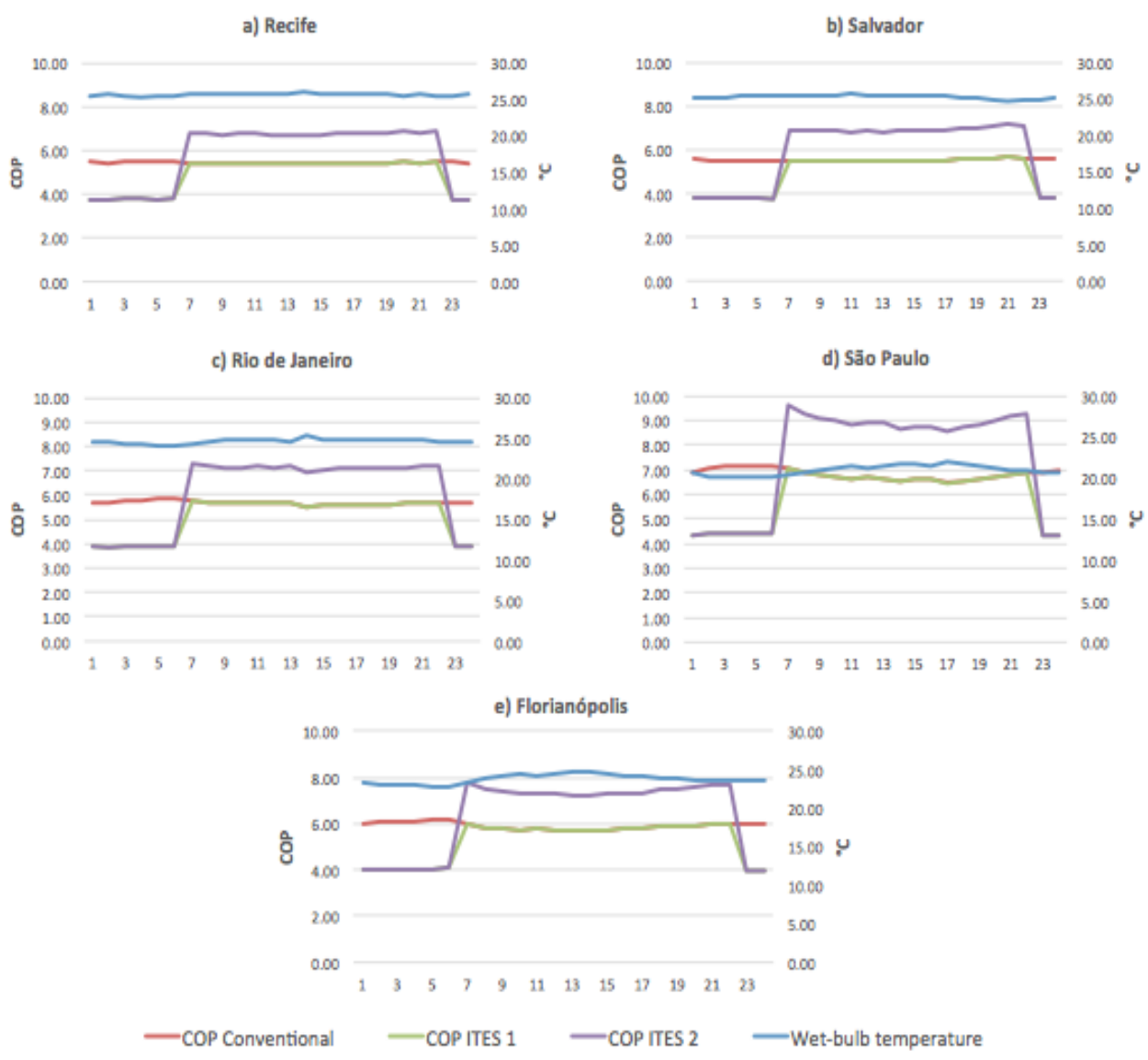

Figure 11 - COP curves for a water-cooled chiller on design day

Results indicate that the COP penalty for the ice-making process can vary between $30-40 \%$ in cities in Brazil, with water-cooled chillers presenting slightly higher COP penalties than air-cooled chillers due to lower variations on the outdoor wet-bulb temperature (compared to dry-bulb temperature) from daytime to night-time. It is also possible to notice that ITES 2 may present higher COP than ITES 1 and conventional systems during daytime operation (20-30\% higher) due to its configuration as chiller priority (chiller upstream) on partial storage, where the chiller delivers cold glycol-water at higher temperatures to the ice tanks. Figure 5 presented the temperatures considered in each stage, depending on the ITES strategy. Although water-cooled chillers present higher COP and therefore lower electricity demand than air-cooled chillers, a more detailed analysis would also need to consider the energy needed to run the pumps and fans of the cooling tower/condenser circuit.

As AC systems are designed in TR, the electricity demand $(\mathrm{kW})$ is estimated by dividing the value in $\mathrm{kW}$ of heat (which is found dividing the TR value by 3.51) by the COP values shown in Figure 10 and Figure 11 for each hour of the day. 
Figure 12 shows the electricity demand for AC systems in Recife and São Paulo, for a large-office building on design day.
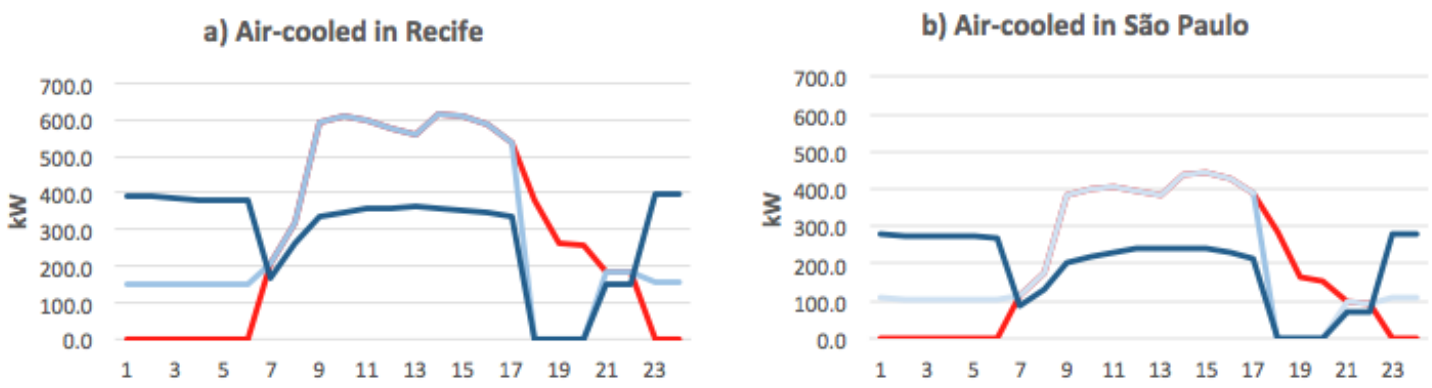

c) Water-cooled in Recife

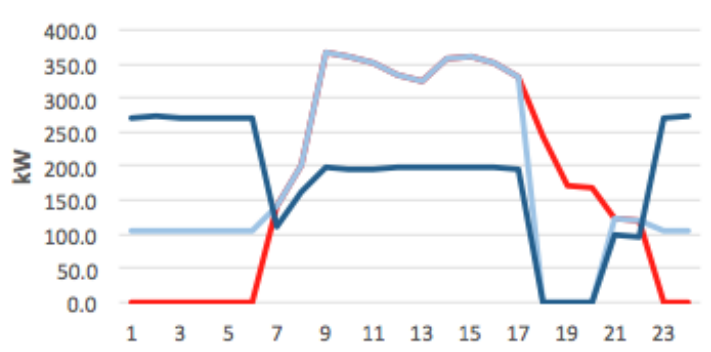

d) Water-cooled in São Paulo

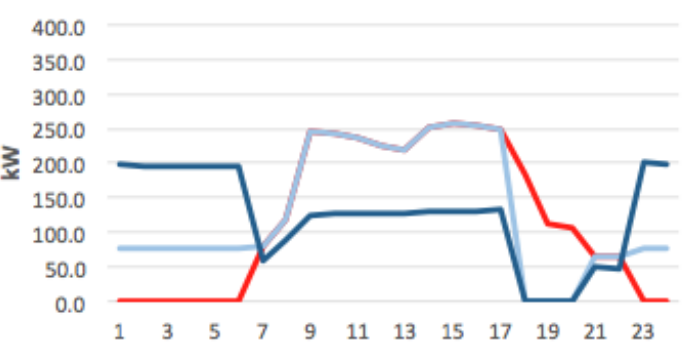

Conventional - ITES $1 \quad$ ITES 2

Figure 12 - Electricity demand of a large-office in Recife and São Paulo

For hospitals and hotels, the chiller's electricity consumption during the night can be higher than that of daytime for ITES 1 systems due to night-time cooling load and the COP penalty for ice-making. Figure 13 and Figure 14 shows the electricity demand for AC systems in Recife and São Paulo, for hospital and hotel buildings on design day. 
a) Air-cooled in Recife

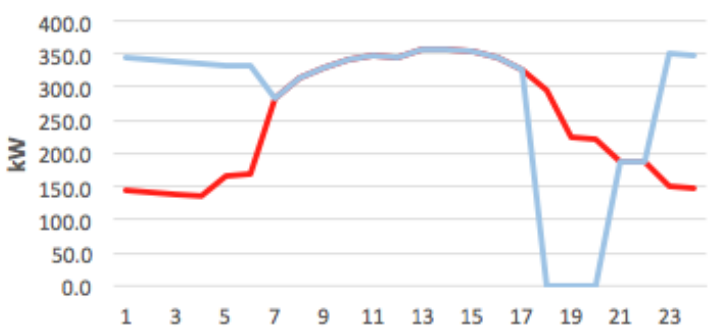

c) Water-cooled in Recife

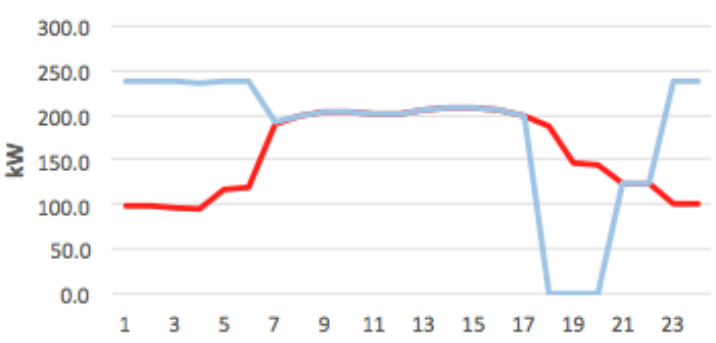

b) Air-cooled in São Paulo

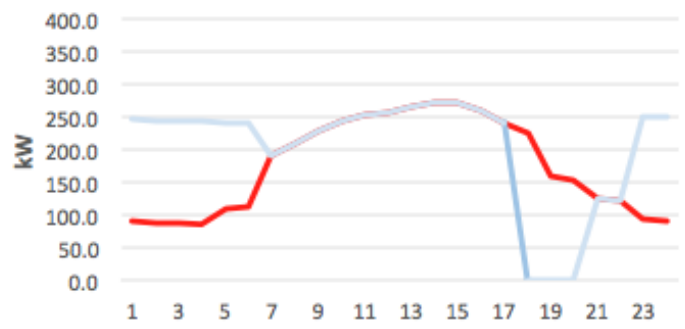

d) Water-cooled in São Paulo

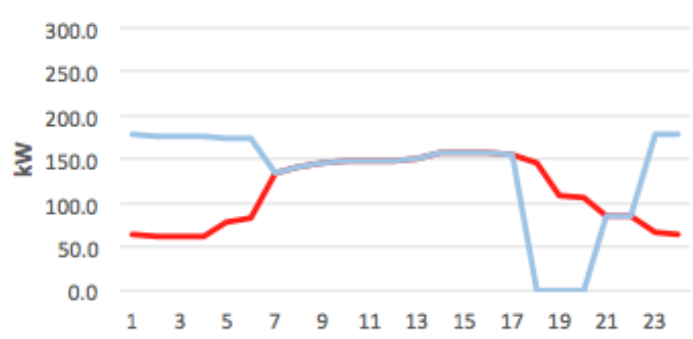

Conventional

Figure 13 - Electricity demand of a hospital in Recife and São Paulo

a) Air-cooled in Recife

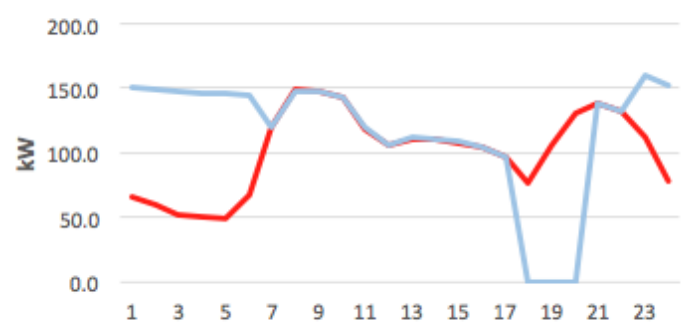

c) Water-cooled in Recife

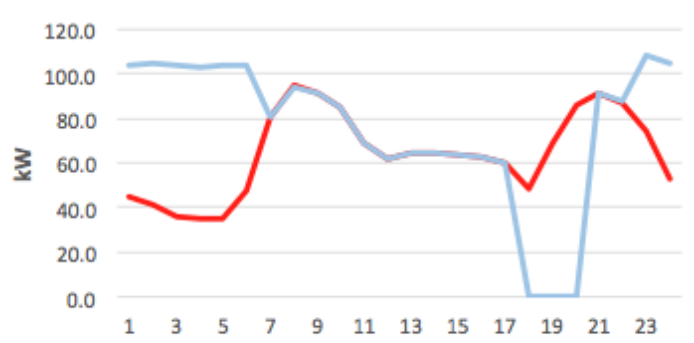

b) Air-cooled in São Paulo

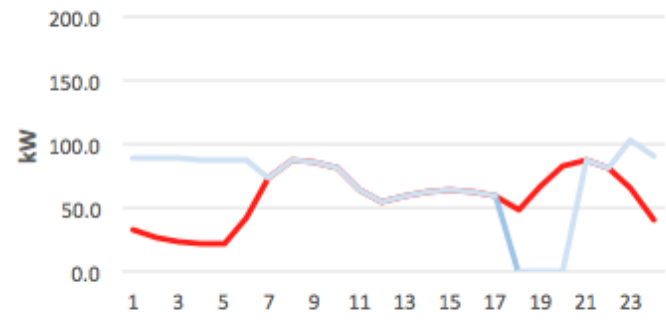

d) Water-cooled in São Paulo

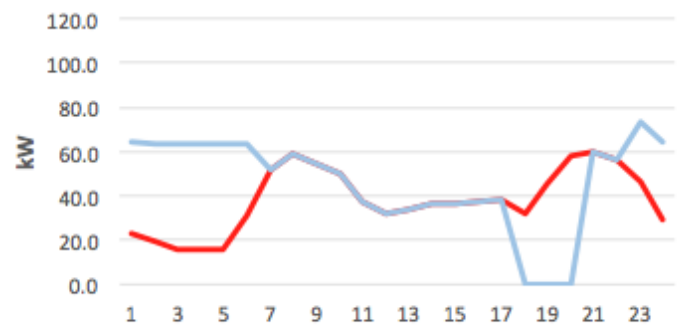

Conventional $\quad$ - ITES 1

Figure 14 - Electricity demand of a hotel in Recife and São Paulo

To calculate the annual energy consumption and costs, the average cooling load profile is used instead of the design day cooling load profile. Figure 15 and Figure 16 illustrates the annual energy consumption of AC systems in large- 
office and hospital buildings in Brazil.

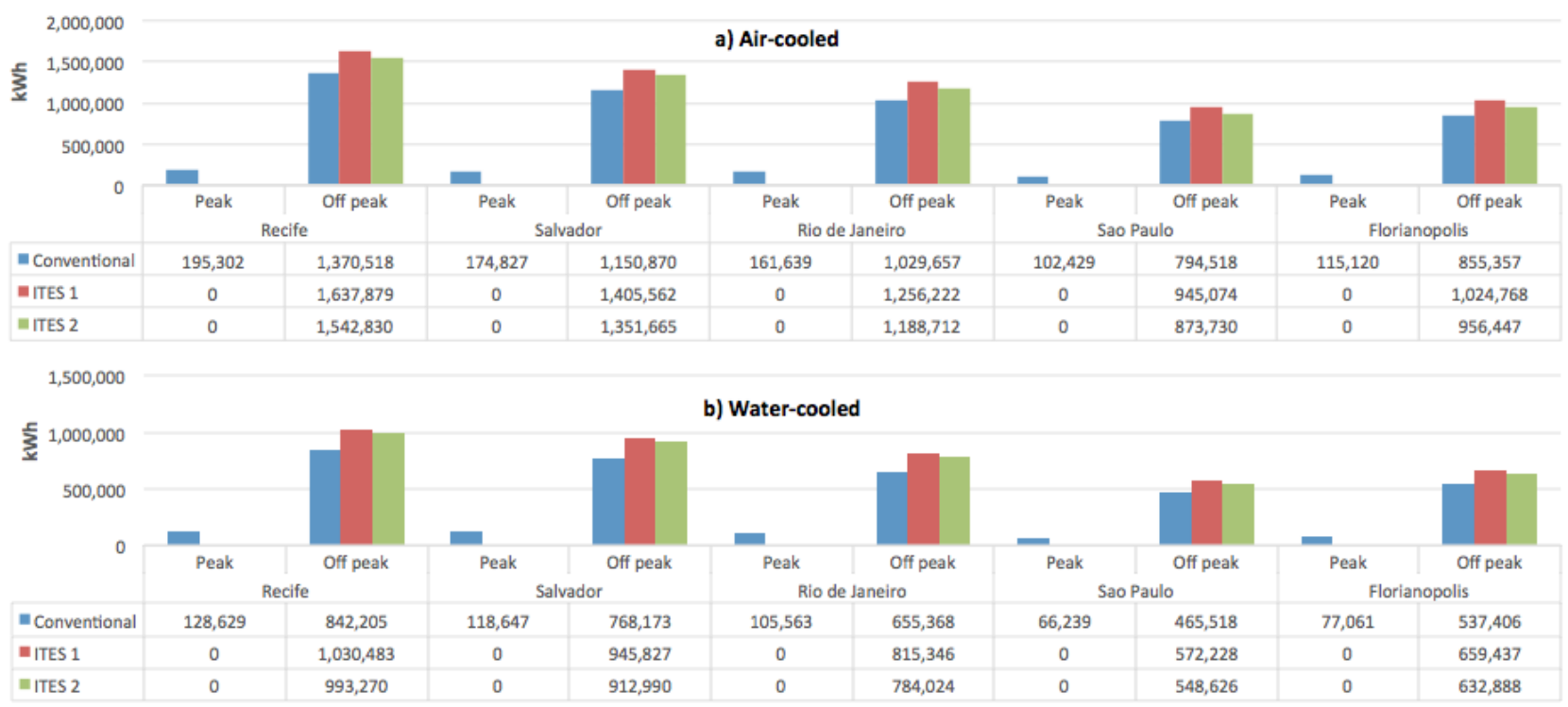

Figure 15 - Annual electricity consumption of AC systems in a large-office

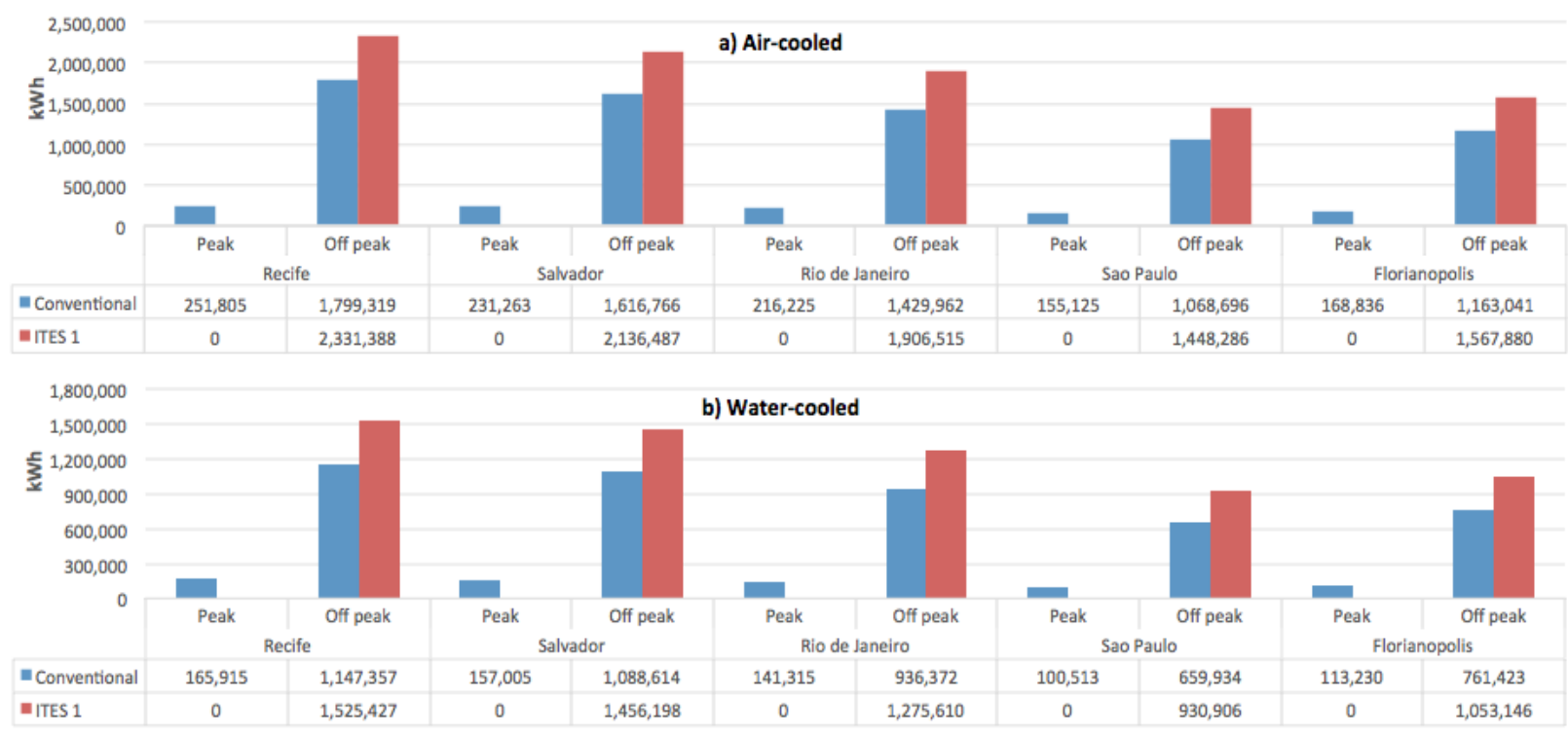

Figure 16 - Annual electricity consumption of AC systems in a hospital

The results indicate that AC systems in Recife and Salvador would present higher energy consumption than São Paulo and Florianópolis due to higher ambient temperatures. ITES 1 presented higher overall consumption than ITES 2 systems in all cases, due to the higher ITES 2 COP during daytime operation. In some cases, ITES 2 might present lower overall consumption than conventional systems as well. For buildings with night-time cooling load, ITES would always present higher energy consumption than conventional systems. 


\subsection{Economic analysis}

With the electricity demand $(\mathrm{kW})$, annual consumption $(\mathrm{kWh})$ and tariffs as presented in Table 3, it is possible to estimate the annual energy costs. ITES systems provided medium-office, large-office, and school buildings owners with savings in all cases. However, as the cooling load and costs of energy vary from city to city, ITES systems would generate more economic gains in certain cases. Recife and Salvador not only have the hotter climates but also the higher energy tariffs, whereas São Paulo presents the coldest climate and the lowest energy tariffs. Table 5 shows the annual savings with electricity for each city and tariff scheme (Blue and Green), when ITES 1 and 2 are compared to conventional systems in large-office buildings.

Table 5 - Large-office annual savings with tariffs (R\$)

\begin{tabular}{ccccccc}
\cline { 3 - 7 } & & Recife & Salvador & $\begin{array}{c}\text { Rio de } \\
\text { Janeiro }\end{array}$ & São Paulo & Florianopolis \\
\hline Air-cooled & & & & & & \\
\hline \multirow{2}{*}{ ITES 1 } & Blue & 207,436 & 253,064 & 131,462 & 37,573 & 94,500 \\
& Green & 310,031 & 380,145 & 217,185 & 64,493 & 140,004 \\
\multirow{2}{*}{ ITES 2 } & Blue & 372,624 & 310,659 & 205,101 & 82,026 & 149,011 \\
& Green & 389,947 & 437,740 & 290,824 & 108,947 & 194,515 \\
\hline Water-cooled & & & & & & \\
\hline \multirow{2}{*}{ ITES 1 } & Blue & 130,417 & 168,590 & 77,623 & 20,360 & 57,654 \\
& Green & 199,074 & 255,766 & 134,091 & 37,982 & 89,037 \\
ITES 2 & Blue & 200,227 & 203,827 & 110,813 & 34,385 & 78,803 \\
& Green & 232,122 & 291,002 & 167,281 & 52,008 & 110,186 \\
\hline
\end{tabular}

Based on the chiller and storage sizes, and equipment costs as presented in Table 4, it is possible to estimate the total CAPEX for new installations and retrofits. Table 6 shows that CAPEX for ITES 1 and 2 systems in large-office buildings, in comparison to conventional systems.

Table 6 - Large-office CAPEX of new installations and retrofits (R\$)

\begin{tabular}{cccccc}
\cline { 2 - 6 } New Installations & Recife & Salvador & $\begin{array}{c}\text { Rio de } \\
\text { Janeiro }\end{array}$ & São Paulo & Florianopolis \\
\hline Air-cooled & & & & 315,000 & 315,000 \\
\hline ITES 1 & 360,000 & 315,000 & 360,000 & 156,028 & 174,087 \\
ITES 2 & 182,976 & 152,969 & 185,597 & & 315,000 \\
\hline Water-cooled & & & & 315,000 & 88,766 \\
\hline ITES 1 & 360,000 & 315,000 & 360,000 & & \\
ITES 2 & 80,814 & 53,920 & 93,322 & 66,957 & \\
\hline Retrofit & & & &
\end{tabular}




\begin{tabular}{llllll}
\hline ITES 1 & 360,000 & 315,000 & 360,000 & 315,000 & 315,000 \\
ITES 2 & 675,000 & 630,000 & 630,000 & 585,000 & 585,000 \\
\hline
\end{tabular}

In new installations, ITES 2 presented lower CAPEX than ITES 1 systems due to downsized chillers, even though more storage is needed, but the opposite is true for retrofits where only the costs of storage are considered. The attractiveness of the ITES solution vary widely depending on the weather and energy tariffs, as confirmed in Table 7 and Table 8.

Table 7 - Large-office payback (yrs) for new installations and retrofits, in Salvador and São Paulo

\begin{tabular}{|c|c|c|c|c|c|}
\hline \multirow{2}{*}{\multicolumn{2}{|c|}{ New installations }} & \multicolumn{2}{|c|}{ Blue Tariff } & \multicolumn{2}{|c|}{ Green Tariff } \\
\hline & & Air-cooled & $\begin{array}{l}\text { Water- } \\
\text { cooled }\end{array}$ & Air-cooled & $\begin{array}{l}\text { Water- } \\
\text { cooled }\end{array}$ \\
\hline \multirow{2}{*}{ Salvador } & ITES 1 & 1.2 & 1.9 & 0.8 & 1.2 \\
\hline & ITES 2 & 0.5 & 0.3 & 0.3 & 0.2 \\
\hline \multirow{2}{*}{ São Paulo } & ITES 1 & 8.4 & 15.5 & 4.9 & 8.3 \\
\hline & ITES 2 & 1.9 & 1.9 & 1.4 & 1.3 \\
\hline \multicolumn{6}{|c|}{ Retrofits } \\
\hline \multirow{2}{*}{ Salvador } & ITES 1 & 1.2 & 1.9 & 0.8 & 1.2 \\
\hline & ITES 2 & 2.0 & 3.1 & 1.4 & 2.2 \\
\hline \multirow{2}{*}{ São Paulo } & ITES 1 & 8.4 & 15.5 & 4.9 & 8.3 \\
\hline & ITES 2 & 7.1 & 17.0 & 5.4 & 11.2 \\
\hline
\end{tabular}

Table 8 - Large-office IRR (\%/a) for new installations and retrofits, in Salvador and São Paulo

\begin{tabular}{lccccc}
\multirow{2}{*}{ New installations } & \multicolumn{2}{c}{ Blue Tariff } & \multicolumn{2}{c}{ Green Tariff } \\
\cline { 3 - 6 } & & Air-cooled & $\begin{array}{c}\text { Water- } \\
\text { cooled }\end{array}$ & Air-cooled & $\begin{array}{c}\text { Water- } \\
\text { cooled }\end{array}$ \\
\hline \multirow{2}{*}{ Salvador } & ITES 1 & $80 \%$ & $53 \%$ & $121 \%$ & $81 \%$ \\
& ITES 2 & $203 \%$ & $77 \%$ & $286 \%$ & $110 \%$ \\
\hline \multirow{2}{*}{ São Paulo } & ITES 1 & $3 \%$ & $-7 \%$ & $16 \%$ & $4 \%$ \\
& ITES 2 & $52 \%$ & $6 \%$ & $69 \%$ & $16 \%$ \\
\hline \multicolumn{2}{c}{ Retrofits } & & & & \\
\hline \multirow{2}{*}{ Salvador } & ITES 1 & $80 \%$ & $53 \%$ & $121 \%$ & $81 \%$ \\
\hline \multirow{2}{*}{ São Paulo } & ITES 2 & $48 \%$ & $30 \%$ & $69 \%$ & $45 \%$ \\
\hline
\end{tabular}

It is clear that an ITES system would be more cost-effective in cities with hotter climates and higher energy costs, such as Salvador. The same system (ITES 2, Green Tariff, Air-cooled, retrofit) can have a payback time varying from 1.4 years in Salvador to 5.4 years in São Paulo. In São Paulo a maximum payback 
time of 17 years was estimated for a retrofit, ITES 2, water-cooled system under the Blue tariff. The IRR also confirms that the attractiveness of the ITES solution varies significantly depending on the weather and energy tariffs. Medium-office and school buildings presented similar results.

However, ITES systems might provide building owners with losses in some cases, as found in the hospital and hotel cases. Table 9 shows the annual savings or losses with electricity when ITES 1 is compared to conventional systems in hospital buildings.

Table 9 - Hospital annual savings or losses with tariffs (R\$)

\begin{tabular}{ccccccc}
\cline { 3 - 6 } & & Recife & Salvador & $\begin{array}{c}\text { Rio de } \\
\text { Janeiro }\end{array}$ & São Paulo & Florianópolis \\
\hline \multirow{2}{*}{ Air-cooled } & Blue & 101,295 & 108,938 & -995 & $-22,607$ & 7,239 \\
& Green & 296,818 & 316,148 & 146,756 & 27,503 & 109,370 \\
\multirow{2}{*}{ Water-cooled } & Blue & 39,900 & 65,952 & $-23,556$ & $-26,105$ & $-9,130$ \\
& Green & 179,631 & 207,231 & 73,425 & 6,573 & 60,235 \\
\hline
\end{tabular}

The CAPEX for ITES systems in hospital buildings, in comparison to conventional systems, is presented in Table $\mathbf{1 0 .}$

Table 10 - Hospital CAPEX of new installations and retrofits (R\$)

\begin{tabular}{cccccc}
\cline { 2 - 6 } New Installations & Recife & Salvador & $\begin{array}{c}\text { Rio de } \\
\text { Janeiro }\end{array}$ & São Paulo & Florianopolis \\
\hline Air-cooled & 346,695 & 324,376 & 306,406 & 270,000 & 280,606 \\
Water-cooled & 353,276 & 335,666 & 313,965 & 270,000 & 282,808 \\
\hline Retrofit & & & & & \\
\hline ITES 1 & 315,000 & 270,000 & 270,000 & 270,000 & 270,000 \\
\hline
\end{tabular}

As ITES 1 systems in hospital buildings in Recife, Salvador, Rio de Janeiro and Florianópolis would require larger chillers than conventional systems, the retrofit case would need to assess the capacity of existing chillers. If the existing chiller can operate at the required capacity to generate cooling and ice during nighttime, a retrofit can be considered. The CAPEX difference between new installations and retrofits of ITES 1 systems, as seen in Table 10, reflects not only the costs of storage but also the costs of larger chillers. As mentioned before, ITES systems might lead to annual losses in hospital buildings, which are represented in Table 11 as "Negative Cash Flow". Hotel buildings presented similar results. 
Table 11 - Hospital payback (yrs) and IRR (\%/a) of a retrofit, in Salvador and São Paulo

\begin{tabular}{lcccc} 
& \multicolumn{2}{c}{ Blue Tariff } & \multicolumn{2}{c}{ Green Tariff } \\
\cline { 2 - 5 } Payback & Air-cooled & Water-cooled & Air-cooled & Water-cooled \\
\hline Salvador & 2.5 & 4.1 & 0.9 & 1.3 \\
São Paulo & Negative cash flow & Negative cash flow & 9.8 & 41.1 \\
\hline IRR & & & $117 \%$ & $76 \%$ \\
\hline Salvador & $39 \%$ & $21 \%$ & $0 \%$ & $-20 \%$ \\
São Paulo & Negative cash flow & Negative cash flow & $0 \%$ \\
\hline
\end{tabular}

\section{Conclusions}

By creating a library of cooling load profiles for commercial buildings in Brazil and designing ITES systems to reduce energy costs for building owners, this research assessed the technical and economic aspects of the solution. The use of ITES to shift the building's cooling load to off-peak time might generate economic gains for buildings owners, however, this is highly dependent on the cooling load profile, the adopted ITES strategy and tariff schemes. Results show that ITES can effectively shape peak demand in commercial buildings in Brazil, shifting not only on-peak tariff time demand to off-peak tariff time, but also daytime cooling demand to night-time (ITES 2). Although overall energy consumption of AC systems is generally higher with ITES, on-peak demand can be fully or partially eliminated. The changes in the country's peak demand during the summer are still under investigation, however, it is already accepted that the intensive use of air-conditioning is one of the factors causing this load shift from current on-peak tariff time to off-peak tariff time. The role of ITES in AC load management must be considered in these investigations, as the technology's potential to shape electricity demand in the commercial sector can encourage Brazil's policy makers, regulators, grid operators and utilities in considering ITES as an option to reduce peak demand, increase security of supply and support the integration of intermittent renewable generation. It is essential to raise awareness of the ITES solution to stakeholders in Brazil's energy sector, including building owners and AC systems designers.

Although this study focused on reducing energy costs for building owners with the particular tariff scheme currently implemented in Brazil, ITES can be easily adapted to other tariff schemes or demand response strategies. Future tariff schemes in Brazil could be designed to incentivise the uptake of AC load management measures such as CTES, and more specifically ITES. An alternative to be considered would be to offer a special night-time tariff (from 22:00 to 
06:00), cheaper than the current off-peak tariff, as proposed by Vieira (2009). The climate plays an important role in determining the attractiveness of ITES, however, the electricity tariffs vary significantly from city to city in Brazil and this determined the economic feasibility of the ITES solution. It is important to highlight that ITES systems require further investigation depending on the local situation, which can vary widely from one building to the other. New installations and retrofits require available space for additional equipment, including storage tanks, which can affect the feasibility of the project. The retrofit case would also need to assess the capacity of the existing chiller, as ITES systems in hospitals and hotels might require larger chillers than conventional systems due to reduced capacity during ice-making time.

\section{Acknowledgments}

The authors wish to thank Chevening Scholarships, the UK government's global scholarship programme funded by the Foreign and Commonwealth Office (FCO) and partner organisations. Thanks also to Antonio Chiachia (Alpina CALMAC) and Ayra Mayone (Climapress) for the support and valuable guidance on the Brazilian ITES and HVAC market.

\section{References}

AES Eletropaulo. 2016. Tarifa de energia elétrica. Retrieved July 20, 2016, from https:/www.aeseletropaulo.com.br/poder-publico/prazos-e-tarifas/conteudo/tarifa-deenergia-eletrica

Akbari, H., \& Sezgen, O. 1992. Case Studies of Thermal Energy Storage (TES) Systems: Evaluation and Verification of System Performance. Lawrence Berkeley Laboratory. University of California., Berkeley.

Alpina CALMAC. 2007. Artigos e publicações. Retrieved February 13, 2016, from Alpina CALMAC: http://www.alpinacalmac.com.br/artigos/Pal.\%20Calmac.ppt

Alpina CALMAC. 2016a. FUNCIONAMENTO TANQUES DE GELO ALPINA CALMAC. Retrieved July 20, 2016, from Alpina CALMAC:

http://www.alpinacalmac.com.br/funcionamento-tanques-de-gelo-alpina-calmac.php

Alpina CALMAC, 2016b. RES: Dissertação de Mestrado (Londres) - Armazenamento de energia em forma de gelo e pico de eletricidade no Brasil. [Online] Available at: antonio@alpina.com.br [Accessed 05 May 2016]. (SI) (pp. 29.1-29.40). Atlanta, GA: ASHRAE. 
ASHRAE. 2007. ASHRAE Handbook: Heating, Ventilating, and Air-Conditioning Applications,. Atlanta: American Society of Heating Refrigerating and Air-Conditioning Engineers.

Bahnfleth, W. P., \& Reindl, D. T. 1998. Prospects for cool thermal storage in a competitive electric power industry. ASCE Journal of Architectural Engineering , 4 (1), 18-25.

Beggs, C. B., \& Ward, I. C. 1992. Ice storage: Design study of the factors affecting installations. Building Serv. Eng. Res. Technol. , 13 (2), 49-59.

Celesc. 2016. Tarifas. Retrieved July 20, 2016, from http://novoportal.celesc.com.br/portal/index.php/duvidas-mais-frequentes/1140-tarifa

Celpe. 2016. Tarifas Grupo A. Retrieved July 20, 2016, from http://servicos.celpe.com.br/comercial-industrial/Pages/Alta\%20Tens\%C3\%A3o/tarifasgrupo-a.aspx

Climapress, 2016. Consumo de energia de sistemas HVAC. [Online] Available at: ayra.souza@climapress.com.br [Accessed 04 August 2016].

Coelba. 2016. Tarifas Grupo A. Retrieved July 20, 2016, from http://servicos.coelba.com.br/comercial-industrial/Pages/Alta\%20Tens\%C3\%A3o/tarifasgrupo-a.aspx

Condessa, G. M., \& Neto, J. M. 2014. PROJETO BÁSICO DE UM SISTEMA CENTRAL DE AR CONDICIONADO COM TERMOACUMULAÇÃO PARA O CAMPUS II DO CEFET-MG. MERCOFRIO 2014 - 9o CONGRESSO INTERNACIONAL DE AR CONDICIONADO, REFRIGERAÇÃO, AQUECIMENTO E VENTILAÇÃO.

Cortez, L., Silveira Jr., V., Neves Filho, L., da Silva, F., Afonso, M., Nunes, S., et al. 2003. Racionalização da Curva de Demanda de Energia Elétrica em Sistemas de Ar Condicionado com Termo-Acumulação. ANAIS II DO CITENEL.

Crane, M., \& Dunlop, C. 1994. Ice storage system for a department store. ASHRAE Journal , $36,49-52$.

Dinçer, I., \& Rosen, M. 2011. THERMAL ENERGY STORAGE: SYSTEMS AND APPLICATIONS (2nd ed.). Ontario, Canada: John Wiley \& Sons.

Donnely, E. 2012. Comparison of Ice-Bank Actual Results Against Simulated Predicted Results in Carroll Refurbishment Project DKIT. SDAR* Journal of Sustainable Design \& Applied $, l(2), 26-36$.

EPE. 2014. Resenha Mensal do Mercado de Energia Elétrica - Março 2014. Empresa de Pesquisa Energética. Rio de Janeiro: EPE.

EPE. 2015a. Resenha Mensal do Mercado de Energia Elétrica - Fevereiro 2015. Empresa de Pesquisa Energética. Rio de Janeiro: EPE.

EPE. 2015b. NOTA TÉCNICA DEA 01/15 Estimativa da Capacidade Instalada de Geração Distribuída no SIN: Aplicações no Horário de Ponta. Technical Report. 
Frota, A. B., \& Schiffer, R. S. 2011. Manual de Conforto Térmico (5 ed.). São Paulo: Studio Nobel.

Habeebullah, B. A. 2007. Economic feasibility of thermal energy storage systems. Energy and Buildings , 39, 355-363.

Hasnain, S. 1998. REVIEW ON SUSTAINABLE THERMAL ENERGY STORAGE TECHNOLOGIES, PART II: COOL THERMAL STORAGE. Energy Convers. Mgmt , $39,1139-1153$.

Henze, P. G. 1995. EVALUATION OF OPTIMAL CONTROL FOR ICE STORAGE SYSTEMS. $\mathrm{Ph} . \mathrm{D}$. Dissertation, Faculty of the Graduate Scho ol of the University of Colorado, Boulder, Colorado.

IBGE. 2016. Cidades IBGE. Retrieved Jul 20, 2016, from http://www.cidades.ibge.gov.br/

Ice-Energy. 2016. Technology - Ice-Energy. Retrieved June 1, 2016, from Ice-Energy: https://www.ice-energy.com/technology/

INMETRO. 2012. Regulamento Técnico da Qualidade para o Nivel de Eficiência Energética de Edificações Comerciais, de Serviços e Públicas (RTQ-C). Instituto Nacional de Metrologia, Normalização e Qualidade Industrial (INMETRO), Brasil, Portaria 17, de 16 de Janeiro de 2012.

Light. 2016. Composição da Tarifa. Retrieved July 20, 2016, from http://www.light.com.br/para-residencias/Sua-Conta/composicao-da-tarifa.aspx

MacCracken, M. M. 2003. Thermal Energy Storage Myths. ASHRAE Journal September, 36-42.

MacCracken, M. M. 2010. Energy Storage: Providing for a Low-Carbon Future. ASHRAE Journal September, 28-36.

Melo, A. P., Sorgato, M.J., Lamberts, R.. 2014. Building energy performance assessment: Comparison between ASHRAE standard 90.1 and Brazilian regulation. Energy and Buildings, 70, 372-383.

MME. 2014. Boletim Mensal de Monitoramento do Sistema Elétrico Brasileiro. Fevereiro 2014. Ministério de Minas e Energia. Brasília: MME.

MME. 2015. Boletim Mensal de Monitoramento do Sistema Elétrico Brasileiro. Janeiro - 2015. Ministério de Minas e Energia. Brasília: MME.

NREL. 2011. Commercial Reference Building Models of the National Building Stock. Technical Report, National Renewable Energy Laboratory, Golden, CO.

Parameshwaran, R., Kalaiselvam, S., Harikrishnan, S., \& Elayaperumal, A. 2012. Sustainable thermal energy storage technologies for buildings: A review. Renewable and Sustainable Energy Reviews , 16, 2394-2433.

PROCEL. 2008. Pesquisa de Posse de Equipamentos e Hábitos de Uso. Classe comercial - Alta tensão - Relatório Brasil - Completo. PROCEL/ELETROBRAS, Rio de Janeiro. 
Rismanchi, B., Saidur, R., Masjuki , H., \& Mahlia , T. 2012. Energetic, economic and environmental benefits of utilizing the ice thermal storage systems for office building applications. Energy and Buildings , 50, 347-354.

Rismanchi, B., Saidur, R., Masjuki, H., \& Mahlia, T. 2013. Modeling and simulation to determine the potential energy savings by implementing cold thermal energy storage system in office buildings. Energy Conversion and Management , 75, 152-161.

Sehar, F., Rahman, S., \& Pipattanasomporn, M. 2012. Impacts of ice storage on electrical energy consumptions in office buildings. Energy and Buildings , 51, 255-262.

Sehar, F., Pipattanasomporn, M., \& Rahman, S. 2016. An energy management model to study energy and peak power savings from $\mathrm{PV}$ and storage in demand responsive buildings. Applied Energy , 173, 406-417.

Silvetti, B. 2002. Application Fundamentals Of Ice-Based Thermal Storage. ASHRAE Journal February, 30-35.

SMACNA BRASIL. 1993. Uso racional de energia em condicionamento de ar. SMACPAPER Cientifico , 2, pp. 1-6.

Sohn, C., Cler, G., \& Kedl, R. 1990. Ice-on-Coil Diurnal Ice Storage Cooling System for a Barracks/Office/Dining Hall Facility at Yuma Proving Ground, AZ. Technical Report, US Army Corps of Engineers.

Spataru, C., Barrett, M., Kok, Y. C.. 2014. Physical energy storage employed worldwide. Energy Procedia , 62, 452-461.

SWERA. 2016. Weather Data by Region All Regions - South America WMO Region 3 - Brazil. Retrieved April 15, 2016, from EnergyPlus: https://energyplus.net/weatherregion/south_america_wmo_region_3/BRA $\% 20 \% 20$

Trane. 2009. Ice Storage: Design and Application.

Vieira, F. A. 2009. Termoacumulação: avaliação regulatória de uma alternativa eficaz para a melhoria do fator de carga. Master's dissertation, Pontifícia Universidade Católica do Rio de Janeiro - PUC RJ, Rio de Janeiro.

$\mathrm{Wu}$, C.-T., \& Yao-Hsu, T. 2015. Design of an ice thermal energy storage system for a building of hospitality operation. International Journal of Hospitality Management , 46, 46-54.

Yau, Y., \& Rismanchi, B. 2012. A review on cool thermal storage technologies and operating strategies. Renewable and Sustainable Energy Reviews , 16, 787-797.

Yin, R., Black, D., Piette, M., \& Schiess, K. 2015. Control of Thermal Energy Storage in Commercial Buildings for California Utility Tariffs and Demand Response. Final Project, Lawrence Berkeley National Laboratory, Berjeley, CA. 